\title{
A Greater Price for a Greater Good? \\ Evidence that Consumers Pay More for Charity-Linked Products
}

\author{
Daniel W. Elfenbein and Brian McManus ${ }^{*}$ \\ Olin Business School \\ Washington University in St Louis
}

October 2007

\begin{abstract}
Consumers consistently express a willingness to favor socially responsible firms, but will they actually pay more for products linked to charitable donations, green production, and similar activities? To answer this question, we analyze a novel data set that matches identical products sold on eBay via charity and non-charity auctions. Items sold through charity auctions have prices that are $6 \%$ higher, on average, than those in non-charity auctions. Bidders appear to value charity auction revenue as a public good, as they submit bids relatively early within charity auctions, which stimulates other bidders to bid more aggressively.
\end{abstract}

Keywords: Charity auctions, cause-related marketing, online auctions, corporate philanthropy JEL codes: D44, H41, L81, M14, M31

\footnotetext{
*Email addresses: elfenbein@wustl.edu, mcmanus@wustl.edu. Corresponding author: McManus. Mailing address: Campus Box 1133; Olin Business School; Washington University; St Louis, MO 63130.
} 


\section{Introduction}

A broad and growing set of for-profit enterprises offer products linked to charitable causes, green production, fair trade practices, and similar activities. Target Corporation, the second largest retailer in the Unites States, donates $5 \%$ of its pre-tax profits to charitable groups, as does the Whole Foods Market grocery chain. Starbucks shops serve coffee that is acquired under fair trade standards, and they also offer Ethos bottled water, Starbucks' own brand, which funds contributions to water safety causes. The Gap, Motorola, and Apple all joined the Product (Red) campaign in 2006 to sell merchandise that supports relief from AIDS, tuberculosis, and malaria in Africa. Prominent early adopters of "cause-related marketing" (CRM) efforts include American Express, which in 1983 linked its credit card offers to a campaign to re-open the Statue of Liberty, and Ben \& Jerry's Ice Cream which has historically linked its business to a variety of environmental and social causes. While many factors may motivate firms and their managers to engage in this behavior, these actions may be driven in part by consumers' expressed preference for products offered by socially responsible firms. According to a 1999 survey by Cone/Roper, two-thirds of consumers report that they would favor retailers or brands associated with a good cause, all else equal (Meyer, 1999).

Whether consumers actually will pay more for charity-linked products is an empirical question. One view is that these products contain an additional favorable attribute, and this should increase demand. An opposing view suggests that consumers may be unwilling to pay more for charity-linked items if their own charitable interests are not aligned with those of the seller. Rather, consumers may prefer to pay competitive prices for non-charity products and then use some of their remaining budgets to support the charities of their choice. ${ }^{1}$ Previous research on cause marketing examines this question mainly by employing surveys to investigate whether consumers will state a preference for products produced by socially responsible firms. ${ }^{2}$ By contrast, we examine consumer behavior in the marketplace. In particular, we provide evidence that consumers will not merely announce an intention to favor charity-linked products; they pay

\footnotetext{
${ }^{1}$ This argument is closely related to Friedman's (1970) critique of socially responsible business objectives, which he argues should be replaced with simple profit maximization. The shareholders of a firm which single-mindedly pursues profit would have the greatest return from their investments, and therefore the greatest available resources for charitable donations which align perfectly with their own tastes.

${ }^{2}$ Examples of empirical research in this style include Strahilevitz and Myers (1998), Sen and Bhattacharya (2001), Lichtenstein, Drumwright, and Braig (2005), and Mohr and Webb (2005). Similarly, Arora and Henderson (2007) use a survey-based methodology to uncover preferences for products with which small donations were associated.
} 
higher prices in auctions to do so. In the online auction market we investigate, we find that consumers are willing to pay about $6 \%$ more, on average, when some or all of their payment goes to a charitable cause selected by a seller. ${ }^{3}$

The primary contribution of this paper is to provide evidence on the puzzle of why firms perform good deeds. Studying firms' motivations in this area deepens our understanding of what outcomes and activities matter within firms' objective functions. Firms' cause-related marketing efforts are often considered along with corporate charitable donations and other forms of “corporate social responsibility" (CSR), which self-interested firms may pursue for many reasons, such as improving visibility, obtaining tax benefits, or reducing production costs. ${ }^{4}$ A common approach to measuring the impact of CSR has been to examine the correlation between corporate financial performance and measures of social responsibility (see Margolis, Elfenbein, and Walsh, 2007, for a meta-analysis of these studies). By focusing on price premiums for products, we take an approach that more closely examines a mechanism that might materially benefit socially responsible firms. ${ }^{5}$ Moreover, we study a market - online auctions at eBay for identical products available with and without a charity component - that offers two advantages over studying the same phenomena in retail settings. Although consumers may frequently encounter charity-linked products in their trips to grocery and department stores, pairs of products (and stores themselves) are generally differentiated by more than their charity association. Examining the market prices for fair trade versus Folger's coffee, for example, would potentially conflate consumers' preferences for fair trade with differences in perceived quality, the impact of brand, and other factors. By contrast we estimate a charity premium using products that are differentiated only by their link to charity. Additionally, within eBay's auctions we have the opportunity to observe a richer set of choices for each consumer relative to a retail market's binary decisions to purchase or not at a posted price. We observe auction closing prices and the duration between each

\footnotetext{
${ }^{3}$ This figure is based on the total amount paid by consumers, including shipping charges. Unless noted, we take this interpretation of prices and premiums when we describe our results. We also report below charity premiums for final prices alone, with shipping fees included as a control variable. Premium estimates which are based on prices inclusive of shipping are typically smaller than those based on final auction prices alone.

${ }^{4}$ See Varadajaran and Menon (1988), Navarro (1988), and Haley (1991) for discussions of why profit-maximizing firms might engage in charitable giving. In contrast to cost-increasing green production, CSR may lead to decreased production costs if worker motivation is improved or the firm gains access to politically allocated resources. See Brammer et al. (2007) for evidence of the former effect. Additionally, pursuing socially responsible practices may reduce the likelihood of threats by activists to boycott a firm's products (Baron, 2001).

${ }^{5}$ To our knowledge, the paper most similar to our own in this regard is Hiscox and Smyth (2007) who use a field experiment to analyze consumer preferences for products labeled as "fair trade."
} 
consumer's bid and the auction's closing time. This, we argue, allows us to discern that consumers value charity revenue as a public good, a motivation that in retail markets is likely indistinguishable from warm-glow charity motivations, in which other consumers' payments do not generate utility.

The second contribution of this paper is that it is among the first to compare whether charity auctions produce greater revenue than standard auctions. ${ }^{6}$ Recent theoretical models suggest that bidding in charity auctions is more aggressive because charity revenue provides a benefit to bidders, both when they pay the auctioneer themselves and when other bidders pay (Goeree et al., 2005; Engers and McManus, 2007). Bidders' incentives vary with auction format, and most empirical research on charity auctions has focused on which auction format leads to the greatest revenue. ${ }^{7}$ Our paper provides evidence on the more basic issue of what would happen to revenue if the charity element is removed entirely from the auction. We know of two recent empirical papers which study similar issues in charity auctions, although with methods different from our own. Popkowski Leszczyc and Rothkopf (2006) conduct a field experiment and compare auctions with $0 \%, 25 \%$, or $100 \%$ of revenue donated to charity. While they find that overall revenue increases with the donation percentage and that the seller's net revenue is greatest in the $25 \%$-share auction, our paper features auctions with considerably higher prices and a cleaner separation of charity and non-charity auctions. ${ }^{8}$ Second, Chua and Berger (2006) study charity auction revenue on eBay and find that charity auctions actually raise less revenue than non-charity sales. They compare charity and non-charity prices by auction product category (e.g. digital cameras) and by product name, but important variation in product characteristics may still remain.

\footnotetext{
${ }^{6}$ Our paper is also related to research in public economics that considers the return from bundling donation activity with a private benefit. Morgan (2000) and Morgan and Sefton (2000) show that lottery ticket sales can increase funding for public goods, and Landry et al. (2006) report the interesting result that door-to-door fundraising is more successful when physically attractive volunteers request the donations.

${ }^{7}$ Carpenter et al. (2005) execute a field experiment and find that first-price auctions are most lucrative. In laboratory experiments, Onderstal and Schram (2006) find that all-pay auctions are best, and Davis et al. (2003) report that revenues are greater with lotteries than ascending auctions. These lab experiments include non-charity treatments, and the revenue ranking of charity and non-charity sales is ambiguous across mechanisms in each paper.

${ }^{8}$ Popkowski Leszczyc and Rothkopf organized online auctions that were part of the Edmonton Sun's annual Christmas auction. Bidders were attracted to the auction website through ads for the Christmas auction. This may have affected bidding by embittering bidders who believed that they would see only charity auctions, or bidders may have believed that revenue in the standard auctions would ultimately benefit the charity. In the two auction experiments within the paper with non-charity control items, the mean closing prices for non-charity items are $\mathrm{C} \$ 19.13$ and $\mathrm{C} \$ 5.48$.
} 
To improve our understanding of prices and consumer participation in markets with charity-linked products, we develop a simple model of consumer activity. ${ }^{9}$ We assume that a consumer's willingness to pay charity premiums is limited by her diminishing marginal utility from donations and her opportunities to donate directly while purchasing non-charity products. These assumptions yield intuitive bounds on the charity premium magnitudes: at low prices the upper bound on the charity premium is increasing with the fraction of revenue donated, and at higher prices the upper bound on the percentage charity premium declines with the value of the underlying product. Our empirical evidence is broadly consistent with the bounds predicted by the model.

Our data are drawn from eBay's Giving Works charity auction program. Many items sold on Giving Works are offered contemporaneously to similar objects in non-charity eBay auctions. The thickness of the main eBay market allows us to create a novel dataset in which charity auctions are matched with nearly identical items in non-charity auctions. ${ }^{10}$ We identify matched items in a wide range of product categories and prices. With a median closing price of $\$ 41$ and a mean of $\$ 88$, the 2,437 auctions that comprise our data would be expensive to generate in a laboratory or field experiment. eBay sellers who use Giving Works choose both the share of revenue donated and the charity that will receive the donation. Nearly all Giving Works auctions have donation shares of $10 \%$ or $100 \%$. Our main findings are as follows:

- Controlling for auction and seller characteristics, charity-linked products close at significantly greater prices, on average, than the prices of identical non-charity products. In $10 \%$-share auctions this premium is $5 \%$, while in $100 \%$-share auctions the premium is $7 \%$.

- The premium for $100 \%$-share auctions declines monotonically with the value of the noncharity matched products. The average premium in the bottom quartile of the price distribution is $13-15 \%$ and the average premium in the top quartile is roughly $2 \%$, indistinguishable from zero.

\footnotetext{
${ }^{9}$ Identical reasoning may be applied to products that are linked with other public goods, such as linking a car rental with the purchase of a carbon offset.

${ }^{10}$ We use the term "nearly identical" to indicate that the items may be sold by different sellers, with different shipping terms, at different times. We control for these differences in the analysis. While some minor differences in product characteristics remain, the data were constructed to minimize these differences.
} 
- Bidders in 100\%-share charity auctions submit their bids half a day earlier than bidders in non-charity auctions, and this appears to stimulate bidding wars that can generate utility for consumers who regard auction revenue as a public good.

Throughout the analysis, we establish the results are robust to alternative empirical specifications. In addition, we highlight results which suggest that consumers care about the charity aspect of a sale rather than, for example, interpreting a charity link as merely a signal of product quality.

The paper proceeds as follows. We provide a brief overview of eBay and its Giving Works auctions in the next section. In Section 3 we review theory and previous research in three areas related to the present paper: bidding in sealed-bid charity auctions, participation in charity auctions, and bid timing. In Section 4 we review the data. Section 5 contains our empirical results, and Section 6 concludes.

\section{Background on eBay and Giving Works}

\subsection{Product sales on eBay}

Founded in 1995, eBay has emerged as the world's largest auctioneer. At very low cost, sellers can offer an item for sale by describing the item, disclosing a small amount of personal information, and specifying an ending time and method for the sale. While many sales are indeed auctions, there is also a popular "Buy It Now" sales method wherein the seller specifies a fixed price for an item and a length of time for which the product is for sale. In the discussion below, we often use the term "auctions" to include both true auctions and buy-it-now sales. Deviations from this convention should be clear from context. Bajari and Hortacsu (2004) review the institutional details of eBay and internet auctions, and they summarize a broad body of literature that has emerged to examine trade in these markets.

To fix ideas for the discussion below on bid timing, we describe how bidding occurs in true auctions and what information is shared with other eBay bidders. Suppose an auction has an opening price of $\$ 10$ and has a $\$ 1$ minimum bid increment. If Bidder A submits the first bid of the auction at $\$ 20$, he becomes the current leader yet his full bid is not displayed to other potential bidders. Instead, the current price of the object is displayed as $\$ 11$ (the opening price

plus the bid increment). If Bidder B submits the next bid at $\$ 15$, B's bid is reported in the auction's bidding history, and the current price is listed as $\$ 16$ with $\mathrm{A}$ identified as the current leader. If Bidder $\mathrm{C}$ submits a bid of $\$ 30$ and then the auction ends, $\mathrm{C}$ wins the auction at a price 
of $\$ 21$, and the final bidding history displays bids of $\$ 20, \$ 15$, and $\$ 21$ for $\mathrm{A}, \mathrm{B}$, and $\mathrm{C}$. While eBay's bidding system is designed to encourage bidders to submit bids once during an auction, some bidders bid multiple times within a single sale. These bidders are described as naive or incremental bidders in the economics literature on eBay, and they play an important role in the discussion below on bid timing.

\subsection{Giving Works}

Giving Works was launched in November 2003 by eBay and MissionFish, a subsidiary of the not-for-profit Points of Light Foundation, to enable eBay sellers to donate some or all of their auctions' proceeds to charities. ${ }^{11}$ From its launch through October 2007, Giving Works has raised over $\$ 84$ million through more than 1.3 million auctions. Although the median sale price of a Giving Works item in 2006 was about \$10, the program has included several high-profile, high-value items. A lunch for eight with Warren Buffet raised $\$ 620,000$ for Glide, an antipoverty organization based in San Francisco. Giving Works also hosted an auction for the $715^{\text {th }}$ home run baseball hit by Barry Bonds, which sold for $\$ 220,100$ and contributed $10 \%$ of revenue to Big Brothers Big Sisters of America.

Giving Works permits sellers to donate between $10 \%$ and $100 \%$ of auction revenue (in $5 \%$ increments) to over 10,000 different charities that are registered with MissionFish. The seller receives the full tax benefit of the donated charity auction revenue. Successful bidders are not to able claim any portion of their payments as tax-deductible.

During the sample period MissionFish employed two different fee structures for charity auctions. Until September 13, 2006 MissionFish deducted $\$ 3$ plus $2.9 \%$ of the donation amount as a fee. Additionally, Giving Works placed a floor of $\$ 10$ on the donation amount, regardless of the donation share selected by the seller. ${ }^{12}$ After September 13, the minimum donation was reduced to $\$ 5$ and MissionFish adjusted its fees so that it receives between 3\% and $20 \%$ of the donation, with the fee percentage declining in the donation size. We do not directly study the impact of this price change on bidders' and sellers' incentives in the present paper. In supplementary analysis not presented below, we find that the Mission Fish fee structure and floor, which is not readily apparent to bidders, has no significant effect on bidder behavior.

\footnotetext{
${ }^{11}$ eBay has hosted charity auctions since 2000. Giving Works is a more recent creation.

${ }^{12}$ When a final sale price is less than the floor, all revenue is donated to the charity, minus MissionFish fees.
} 
In the last six months of 2006, roughly 36,000 items were listed for sale on Giving Works at any moment. ${ }^{13}$ Bidders encounter these items in three main ways. First, charity items are listed along with non-charity items when eBay shoppers use the web site's standard product search utilities. ${ }^{14}$ When the results of a product search include charity auction items, these are distinguished from the non-charity items with a small blue-and-yellow ribbon which appears next to the auction title. When a user clicks on an auction title to view a detailed product description, he also learns the identity of the charity and the size of the donation. Second, the MissionFish web site (http://www.missionfish.com) allows users to search for charities by name and charity type and provides links to all products which benefit these charities. Third, eBay's main "front page" may list special promotions including charity auctions.

More than half of the items available through Giving Works are fixed-price items which remain available until a buyer agrees to the seller's stated price. We do not analyze these sales in this paper. Instead, to facilitate the data matching process, we focus on auctions and buy-it-now sales with ending dates.

\section{Bidding and Participation Incentives in Charity Auctions}

In this section we discuss the relationship between our empirical objectives and theory. First, we review the predictions of static charity auction bidding models in order to explain why bidders would bid more in a charity auction than in a standard contest. Second, we present a model of charity auction participation which generates predictions on the size of charity premiums and how they vary with the values of auctioned items. Third, we review the literature on bid timing and argue that bid timing in true eBay auctions allows us to test whether the public goods value of others' payments shifts bidder behavior.

\subsection{Bidding in static charity auctions}

The central feature of a charity auction is that bidders may consider auction revenue to be a public good. That is, bidders may value total auction revenue as well as their own private benefit from winning the object, and the utility from revenue may be independent of which bidder pays

\footnotetext{
${ }^{13}$ In total, approximately 60 million listings are active on eBay.

${ }^{14}$ In supplementary unreported analysis, we find that the web pages of eBay charity auctions are visited no more or less frequently than the web pages of non-charity auctions. This suggests that the positive charity premiums reported here are not driven by these auctions attracting greater attention from potential bidders.
} 
the auctioneer. Previous models of equilibrium charity auction bidding and revenue have primarily considered activity in static, sealed-bid auctions with independent private values (IPV) for the auctioned object (Goeree et al., 2005; Engers and McManus, 2007). In Engers and McManus (2007), bidders receive utility of $\theta \in(0,1)$ for each of their own dollars received by the charity, and utility of $\lambda \in[0,1)$ for each dollar from another bidder, with $\theta \geq \lambda$. The pure public goods effect of charity auction revenue is captured by $\lambda$, and the additional "warm glow" from one's own payments to charity is $\Delta=\theta-\lambda .^{15}$ Bidders are symmetric in their values of $\theta$ and $\lambda$ but vary in their valuations for the auctioned object.

Equilibrium bids are above their IPV levels in a variety of auction formats. We consider here the results on second-price sealed-bid auctions, which are most similar to the ascending auction format used by eBay. With a positive benefit from other bidders' payments $(\lambda>0)$, bidders follow a strategy other than the standard second-price auction rule of bidding one's true valuation. This occurs because the bidder who places second will determine the winner's payment, and this bidder receives additional surplus from increasing his bid conditional on his position in the order of bids. The difference between bids and valuations is greatest for lowvaluation bidders, and when there is no warm glow the difference declines to zero at the top of the type distribution. A positive warm glow from one's own payment leads all bidders to submit bids above their valuations. If the auctioneer donates only a share of revenue, $\sigma \in(0,1]$, to charity, the analysis in Engers and McManus (2007) holds with $\sigma \theta$ and $\sigma \lambda$ replacing $\theta$ and $\lambda$. Bids are increasing in $\sigma$ at all valuations, therefore revenue increases in $\sigma$ as well.

While equilibrium charity auction models have assumed linear benefits from auction revenue for tractability, it is conventional in the literature on the voluntary funding of public goods to include diminishing marginal utility from the public good. ${ }^{16}$ In a second-price auction, this means a positive but declining marginal benefit from the bidder paying more herself or driving up the winner's payment. In an auction for an especially valuable object, bidders would receive substantial utility from auction revenue conditional on bidding their private valuations, so there may be little to gain from further increasing their bids. While we do not provide a

\footnotetext{
${ }^{15}$ This warm glow is commonly included in models of voluntary contributions to public goods to allow for a personal benefit from donation. It is frequently noted that one person's contribution to a large public good generally does not affect the size of the good significantly, so bidders must hold other motivations for giving. See Andreoni (2006) and the references within for additional discussion.
}

${ }^{16}$ See Andreoni (2006) and the references within. 
formal model of bidding in this situation, we conjecture that diminishing marginal utility from charity leads to a smaller percentage premium in charity auctions for more valuable items, all else equal.

Consumer demand in cause-related marketing (CRM) models has several similarities to bidding incentives in charity auctions. A consumer's utility from a charity-linked product depends on his personal taste for the product, his value for the additional charity revenue a purchase will generate, and other consumers' demand for the charity-linked product. In theoretical studies of CRM, Bagnoli and Watts (2003) consider imperfectly competitive markets, and Polishchuk and Firsov (2005) analyze CRM under competition. ${ }^{17}$ Baron (2007) examines the profitability of firms that encounter charity-minded agents as both customers and investors. The CRM strategies of firms are not always beneficial to the charities associated with the marketing efforts. Kotchen (2006) presents a model in which consumers buy a "green" product plus make direct donations to an environmental cause, and he shows that total production of the public good may be greater through donations alone.

\subsection{Bidder participation}

The prior literature on charity auctions has focused on differences in how bidders respond to selling mechanisms when the bidders have no other options to either: (a) seek a different opportunity to buy the same object as sold in the charity auction, or (b) make a direct donation to the charity. Both of these factors are important to actual charitable fundraising. To explore these issues, we temporarily abstract away from the inter-bidder strategic aspects of charity auctions, and assume that bidders and sellers make auction participation decisions based on accurate $e x$ ante beliefs about prices in charity and non-charity auctions for an otherwise identical pair of items. We also ignore bidders' potential tax benefits from out-of-pocket donations. We derive simple conditions on prices which hold in an equilibrium where charity-minded agents participate in charity auctions while agents with no charitable motivation do not.

Assume that there exists a pair of large markets in which all buyers and sellers take prices as fixed. In both markets the same physical good is traded, but in one market a share, $\sigma \in(0,1]$,

\footnotetext{
${ }^{17}$ Bagnoli and Watts (2003) show that differences in duopolists' CRM strategies can create competition-softening product differentiation. Polishchuk and Firsov (2005) show that profit-enhancing price premiums disappear when several firms pursue CRM and are linked to the same charity.
} 
of revenue is donated to a charitable cause. The price in the charity market is $p_{\mathrm{c}}$, and the price in the standard market is $p_{\mathrm{s}}$. To maintain consistency with the rest of this paper, we refer to transactions as "auctions" although sales occur at the fixed prices of $p_{\mathrm{c}}$ and $p_{\mathrm{s}}$. Now consider the actions of two additional agents (bidders) who each receive utility of $v>p_{\mathrm{s}}$ from obtaining one unit of the traded object. Bidder $\mathrm{A}$ is charity-minded and receives utility of $w(x)$ when he transfers $x$ dollars to a charity, through auction revenue and/or direct donations. We interpret $w$ as representing the warm glow benefit of an individual's donation to charity; public goods effects are not central to the present analysis. For convenience, we assume that $w$ takes the form $w(x)=$ $\alpha x$ when $x<d^{*}$, and $w(x)=\alpha d^{*}$ for $x \geq d^{*}$, with $\alpha>1$ and $d^{*}$ interpreted as bidder A's preferred personal donation level. In specifying $\alpha>1$, we allow the bidder to receive a positive inframarginal benefit from dollars donated to charity. Bidder B receives no utility from charity revenue.

The agents are endowed with initial wealth $y$, and utility is linear in the consumption of a numeraire good, the object for sale, and $w$. We assume that $y$ is large enough so that it does not factor into decisions across auctions. If bidder A purchases an object in a non-charity auction, she pays $p_{\mathrm{s}}$ to the seller and then makes a direct donation of $d^{*}$ to the charity. Utility from this action is $\mathrm{U}_{\mathrm{s}}^{\mathrm{A}}=y+v+w\left(d^{*}\right)-p_{\mathrm{s}}-d^{*}$. If A participates in a charity auction, she obtains the good, pays $p_{\mathrm{c}}$ and makes the implicit donation $\sigma p_{\mathrm{c}}$. If $\sigma p_{\mathrm{c}}<d^{*}$ she then makes the direct donation $d^{*}-\sigma p_{\mathrm{c}}$; if $\sigma p_{\mathrm{c}} \geq d^{*}$ no additional donation is made. Let $d_{\mathrm{A}}=\max \left\{0, d^{*}-\sigma p_{\mathrm{c}}\right\}$. Bidder A's utility from the charity auction is $\mathrm{U}_{\mathrm{c}}^{\mathrm{A}}=y+v+w\left(\sigma p_{\mathrm{c}}+d_{\mathrm{A}}\right)-p_{\mathrm{c}}-d_{\mathrm{A}}$. Bidder $\mathrm{B}$ receives utility of $\mathrm{U}^{\mathrm{B}}{ }_{\mathrm{s}}=y+v-p_{\mathrm{s}}$ from the standard auction and $\mathrm{U}^{\mathrm{B}}{ }_{\mathrm{c}}=y+v-p_{\mathrm{c}}$ from the charity auction.

Inequality conditions on $p_{\mathrm{s}}$ and $p_{\mathrm{c}}$ ensure that the two bidders separate appropriately across the auctions. Bidder $\mathrm{B}$ prefers the standard auction when $p_{\mathrm{c}} \geq p_{\mathrm{s}}$, or $\left(p_{\mathrm{c}}-p_{\mathrm{s}}\right) / p_{\mathrm{s}} \geq 0$. Bidder A's preference between the auctions depends on $\sigma$ and the relative prices. When $\sigma=1$ bidder A will pay a premium in the charity auction so long as $p_{\mathrm{c}} \leq p_{\mathrm{s}}+d^{*}$. In terms of a percentage mark-up, this is $\left(p_{\mathrm{c}}-p_{\mathrm{s}}\right) / p_{\mathrm{s}} \leq d^{*} / p_{\mathrm{s}}$. This yields the empirical prediction that items with greater value (higher $p_{\mathrm{s}}$ ) have charity premiums which fall with $p_{\mathrm{s}}$ holding fixed bidders' charity preferences. For charity-minded bidders and $\sigma<1$, we first consider the case of $d^{*}>\sigma p_{\mathrm{c}}$. 
Bidder A prefers the charity auction when $\left(p_{\mathrm{c}}-p_{\mathrm{s}}\right) / p_{\mathrm{s}} \leq \sigma /(1-\sigma) .{ }^{18}$ As long as the charity premium satisfies this condition, bidder A can make his full donation $d^{*}$ while enjoying greater consumption of the numeraire. Once the charity auction closes with prices that are large relative to bidder A's preferred donation, i.e., $d^{*}<\sigma p_{\mathrm{c}}$, the bidder will participate in the charity auction as long as $p_{\mathrm{c}}$ satisfies $\left(p_{\mathrm{c}}-p_{\mathrm{s}}\right) / p_{\mathrm{s}} \leq d^{*} / p_{\mathrm{s}}$, just as in the case of $\sigma=1$. The shaded area in Figure 1 illustrates the range of charity premiums consistent with the model for a fixed $\sigma<1$ and varying $p_{\mathrm{s}}$.

This analysis offers sharp empirical implications for the $10 \%$-share charity auctions that are common in our data. We expect charity prices to be above non-charity prices, but not by more than $11 \%(=\sigma /(1-\sigma))$. Additionally, the introduction of charity auctions does nothing to increase total charity revenue in our model. One factor that can relax both the restriction on charity premiums and the unchanging charity revenue is a transaction cost for individual bidders to identify and donate to a charity. Suppose that all independent donations require the payment of the lump-sum transaction cost $k$. If $0<w\left(d^{*}\right)-d^{*}<k$, then an individual will not donate to charity even though he would receive positive utility from donating without cost. Thus, the charity-minded bidder makes no donation if he participates in the standard auction, and his utility is $\mathrm{U}_{\mathrm{s}}^{\mathrm{A}}=y+v-p_{\mathrm{s}}$. The charity auction allows for a zero-cost transfer to the charity, and utility is $\mathrm{U}^{\mathrm{A}}{ }_{\mathrm{c}}=y+v+w\left(\sigma p_{\mathrm{c}}\right)-p_{\mathrm{c}}$. For $d^{*}>\sigma p_{\mathrm{c}}$, bidder A's benefit from charity revenue is $w\left(\sigma p_{\mathrm{c}}\right)=$ $\alpha \sigma p_{\mathrm{c}}$, and he participates in the charity auction as long as $\left(p_{\mathrm{c}}-p_{\mathrm{s}}\right) / p_{\mathrm{s}} \leq \alpha \sigma /(1-\alpha \sigma)$. The positive inframarginal benefit from donating yields an upper bound for the charity premium that is greater than when $\sigma<1$ and $k=0 .{ }^{19}$ As prices increase relative to the bidder's ideal donation, the maximum charity premium is $\alpha d^{*} / p_{\mathrm{s}}$, which again is decreasing in the price of the non-charity product. Similar patterns in charity premiums appear when $0<k<w\left(d^{*}\right)-d^{*}$ and the transaction cost may prevent charity auction participants from topping-off their implicit donation of $\sigma p_{\mathrm{c}}$.

\footnotetext{
${ }^{18}$ If we repeat the analysis with one charity-minded seller and one selfish seller, each endowed with a single unit of the auctioned object, we find the same condition on prices to ensure separation across auctions. The charity-minded seller must find that the charity auction is the less expensive way to transfer $d^{*}$ dollars to the charity. The selfish seller must anticipate that his own net revenue is not greater in the charity auction.

${ }^{19}$ For example, if $\sigma=0.10$ and $\alpha=1.4$, a charity-minded bidder is willing to participate in a charity auction with a $16.3 \%$ price premium even though it appears that the bidder is over-paying for the auction's donation.
} 
In this participation model we consider bounds on charity premiums for varying prices while holding fixed a charity-minded bidder's donation preferences. As donation preferences (and transaction costs) are likely to vary in the population, observed market-level charity premiums might not decrease with product values even if consumer-level choices accord with the model's upper bound on charity prices. Premiums also may be affected by a difference between the bidder's favorite charity and the charity selected by the seller. A bidder may be content to pay a charity premium when the size of the implicit donation is small relative to his transaction cost of donating to a different charity independently. However, as $p_{\mathrm{s}}$ increases and the bidder considers more valuable items, the maximum charity premium is constrained by a bidder's preferred donation to the seller-selected charity (as above) as well as the utility difference the bidder would experience from shifting a donation from the seller's preferred charity to his own. ${ }^{20}$

\subsection{Bid timing}

Late or last-minute biding, also know as "sniping," is a common occurrence on eBay. This phenomenon has been documented by Roth and Ockenfels (2002) and Bajari and Hortacsu (2003) with field data; by Ariely, Ockenfels, and Roth (2005) in the laboratory; and by Ely and Hossain (2006) in a field experiment. Several explanations have been offered for this practice, including: (a) implicit collusion by bidders to avoid a price war, (b) information withholding by an expert in a common-value auction, and (c) as an optimal response by strategic bidders when they face naive bidders who submit their bids incrementally. ${ }^{21}$ Incremental bidding occurs when a naive bidder initially submits a low bid and then increases her bid in small increments until he is either the high bidder or cannot beat the current high bid at his maximum willingness to pay. In each explanation of sniping, the strategic (one-time) bidder's main motivation is to reduce his own expected payment to the auctioneer. This ultimately leads to a reduction in expected revenue for

\footnotetext{
${ }^{20}$ This suggests that sellers' charity selections might be made strategically, to account for both their own tastes and the expected tastes of bidders.

${ }^{21}$ Explanation (a) requires truly last-minute (or last-second) bidding with a positive probability of bids being lost in submission. In contrast, (c) does not require literal last-minute bidding, as incremental bidders may submit their bids well before the auction's closing time. Ariely, Ockenfels, and Roth (2005) demonstrate that strategic bidders will snipe even if there is no chance of bids being lost, and Ely and Hossain (2006) argue that sniping in privatevalue auctions is primarily useful as a strategy against naive bidders rather than for collusion.
} 
the seller. For the purposes of this paper, a bidder's incentive to snipe is primarily useful to us because it reveals whether bidders value others' payments in a charity auction.

Ely and Hossain (2006) conduct an experiment in which they randomly choose to bid late or early ("squatting") within actual eBay auctions. They find that sniping generates a marginally higher net benefit relative to squatting, while auction revenue and opponents' maximum bids are reduced substantially in sniping treatments. This suggests that bidders who care about auction revenue will find less benefit in sniping than bidders who do not. Moreover, this incentive is salient when bidders have $\lambda>0$ rather than $\theta>0$ while $\lambda=0$. A positive value of $\theta$ alone shifts the valuation distribution by $(1-\theta)^{-1}$ but changes nothing else about the auction. This results in all bidders increasing their maximum bids by $(1-\theta)^{-1}$, and the relative benefits of sniping and squatting are unchanged.

If strategic bidders in charity auctions are less likely to snipe because they care about other bidders' payments, this has implications for the number of bidders and bids observed in a charity auction. Ely and Hossain (2006) show that squatting reduces the number of active bidders and bids, as this strategy effectively deters bidders from entering the auction. Bidders who bid, however, submit higher bids than in the sniping treatments, and naive bidders require a greater number of bids to beat the squatting bidder's price. These results offer additional opportunities to verify that charity auction bid timing yields more aggressive bidding by naive or incremental bidders. ${ }^{22}$

\section{Data}

We assembled the data set of matched charity and non-charity auctions from eBay auctions that closed between March and December 2006. We began by searching eBay Giving Works for items that appeared possible to match to simultaneous non-charity auctions. In assembling potential matches, we were not able to sample randomly across products on Giving Works. Instead, because it is costly to identify charity auctions that can be matched, we focused our search in the product categories that were most likely to yield matches. These categories include consumer electronics, cameras and photography equipment, DVDs, computer equipment, and

\footnotetext{
${ }^{22}$ We use the terms "naive bidder" and "incremental bidder" interchangeably.

${ }^{24}$ We manually select the Priority Mail (or similar) shipping charge for $5 \%$ of our sample, evenly split between charity and non-charity auctions. Our results are unchanged if these observations are omitted from the analysis.
} 
gift certificates. In searching for successful matches, we attempted to identify products that sold at a wide variety of prices and donation shares.

Each search for a valid match began with a charity auction that concluded with a sale. Once we identified a charity auction that appeared useful for this study, we searched for up to five non-charity auctions that ended in a sale within five days of the Giving Works item. Since most eBay auctions last for seven days, this process yielded matched collections of observations on auctions that were open simultaneously. When more than five matches were available we selected the five successful auctions with ending times closest to the charity auction's end time.

We consider items in charity and non-charity auctions to be a match if the products are identical in physical characteristics. For example, all product characteristics observable to a bidder, like model number, color, age, and apparent wear, are considered for the match. If the charity auction product is not new, it is matched to a non-charity product with a described condition that is indistinguishable from the charity item. For additional details on the search and matching process, please see Appendix A.

Not all eBay auctions end in a sale, but our matching process and empirical strategy are designed to minimize the impact of unobserved auction characteristics that might differ systematically between charity and non-charity auctions and affect the sale probability. The product markets on which we focus are relatively thick compared to commonly listed items like jewelry, overstocked clothing items, and one-of-a-kind collectables. The auctions in our data typically have several bidders per item, which means that final prices are likely to reflect the bidding preferences of consumers rather than the potentially idiosyncratic choices of sellers over the opening price or auction format. Moreover, because multiple auctions are required to form a match, it is reasonable to assume that these frequently-traded items allow bidders to form expectations about market-clearing prices, at least for non-charity items, and the very auctions which fail within these product categories are those that would be relatively uninformative about demand.

The matching process yielded a total of 2,437 auctions organized around 723 charity listings, for an average of 2.4 standard auctions per match. Panel A of Table 1 provides summary statistics for all auction data in the sample. The mean sale price is $\$ 88.23$ ( $\$ 41.00$ median), or $\$ 97.63$ ( $\$ 49.00$ median) if shipping charges are included in the total. When the seller provided a default shipping method and price for an item, this is recorded as the shipping 
charge. In instances when the seller permitted bidders to choose among shipping methods with no default, we record the price of US Priority Mail shipping. If Priority Mail was not offered as a shipping option, we select the delivery method most similar to the Priority Mail policy of delivery within two to three days. ${ }^{24}$

Auctions in the sample average 5.7 days in length, and $21 \%$ of the sample's auctions ended when a buyer agreed to a seller-specified buy-it-now price. Roughly $35 \%$ of the items in the sample were sold by "power sellers," an eBay classification indicating that the seller completes more than $\$ 1,000$ per month in eBay transactions, maintains $98 \%$ positive feedback, and has an overall feedback score exceeding 100. eBay calculates feedback scores by summing the winning bidder's feedback $(+1,0,-1)$ on each transaction. Because bidder feedback is almost always positive, we interpret this score as a measure of seller experience. Sellers' feedback scores in the sample vary widely and are highly skewed, with a mean of 5,596 and median of 374. The average number of unique bidders in an auction is 4.45 , and the mean number of bids is 8.83 .

In Panels B and C of Table 1 we report summary statistics for the charity and non-charity sub-samples, respectively. Final prices of charity auctions are higher on average than noncharity matched auctions. Non-charity matched auctions are also shorter and more likely to be completed via buy-it-now. Sellers' experience in non-charity auctions is greater than that of sellers in charity auctions, but sellers are equally likely to be power sellers and do not differ substantially in the fraction of positive feedback. The mean numbers of bids and unique bidders is slightly greater in charity auctions.

In a large majority of our sample, sellers have chosen either to devote $100 \%$ of the proceeds of the sale to charity or 10\% (the minimum amount allowed). These choices represent $59.6 \%$ and $29.1 \%$ of the charity auctions in the sample, respectively. Of the remaining charity levels chosen, most fall between $15 \%$ and $50 \%$. Because of the preponderance of $100 \%$-share auctions in our sample, the average donation level among charity auctions is $66.1 \%$. Across donation shares, the charity items are quite different from each other. The median closing price is $\$ 30$ in $100 \%$-share auctions and $\$ 92$ for $10 \%$-share sales. Within the charity sample, bidders made an average donation of $\$ 49.20$, or $\$ 43.42$ after Missionfish fees. Overall, this represents more than $\$ 31,000$ of net donations to charity. 
As noted above in Section 2.2, sellers chose the charities to which proceeds would be donated. Overall the sellers in our sample selected a wide range set of charities to receive the donations; 330 unique charities appear in our sample. The modal number of appearances for a charity is 1 , as is the median. The mean number of appearances is 2.2. These charities vary widely in their objectives and scale, ranging from UNICEF to local churches and animal shelters. To illustrate the breadth of charities represented, in Table 2 we list alphabetically the first 40 charities that appear in our sample. In additional unreported analysis we have investigated whether charity premiums vary with charity characteristics such as religious affiliation, regional focus, and size. ${ }^{25}$ The premiums appear unaffected by these characteristics.

In some cases, the marginal donation rate at the closing price is not equal to the charity share chosen by the seller. This occurs when the product of the share chosen and the final price does not exceed the minimum donation amount set by Missionfish. In about one third of the $10 \%$-share auctions, the marginal donation rate faced by the buyer is zero. While the marginal donation is zero, the winning bidder's donation is greater than the product of the donation share and the price. It is unclear whether bidders notice these conditions and if the low marginal donation or large total donation are factors in their bidding strategies. In unreported regressions we corroborate our findings using the marginal donation rates rather than the charity share chosen by the seller.

In Panel D we present the percentage difference between charity prices and the average non-charity price in a match, i.e., a preliminary measure of the charity premium. Before shipping is included, the average difference between charity and non-charity prices is $17.1 \%$; however, this number is driven by a handful of observations with unusually large premiums. The median difference is $4.6 \%$. When shipping costs are included in the premium calculation, the average falls to $8.8 \%$ and the median is $3.3 \%$. Figure 2 illustrates the dispersion of charity premiums observed in the data. When shipping charges are included, the $25^{\text {th }}$ percentile premium is $-7.5 \%$ and the $75^{\text {th }}$ percentile premium is $19.0 \%$. Some variation in the premium is due to observable auction and seller characteristics that are captured with control variables in the empirical analysis.

\footnotetext{
${ }^{25}$ For each charity in the data, we have identified that: a) $12.5 \%$ have a religious affiliation or mission, b) $40.3 \%$ appear on the 2006 Forbes Magazine list of 200 largest US nonprofits or have a parent organization on the list, and c) $35.3 \%$ have a regional focus within the US or in a particular part of the world outside of the US.
} 


\section{Empirical Analysis}

Our objective is to investigate whether (and why) consumers will pay more for a charity-linked product. The closing price of an auction is our main outcome of interest, but other events such as the timing and frequency of bidding also allow us to describe bidders' motivations. These endogenous measures of auction performance are influenced by many factors. To introduce notation, we begin by describing the determinants of the winning bidder's payment.

The winner's payment is affected by many factors, including product attributes observed by all market participants and the econometrician, product attributes known to the seller and perhaps the bidders but unobserved by the econometrician, seller characteristics that are fixed before the auction starts, auction characteristics selected by the seller, and the actions of other bidders who participate in the auction. We index auctions by $i$ and let $P R I C E_{i}$ denote the closing

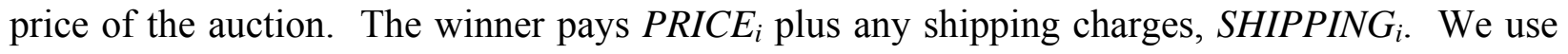
the term "full price" to refer to the total payment of $\left(P R I C E_{i}+S H I P P I N G_{i}\right)$. The common product attributes within a matched set of auctions, $m$, are captured by the match-specific dummy variable, $\alpha_{m}$. Any product and auction characteristics unobserved by the econometrician and varying within $m$ are in the error term $\varepsilon_{i m}$. In most of our analysis we allow for correlation in $\varepsilon$ values within a match, as it is possible for one item's attributes to affect demand for the other matched items. Seller characteristics such as experience and power seller status are taken as exogenous by all agents as auction $i$ begins, and these are collected in the vector SELLER . Individual dummy variables for high-volume sellers, five sellers whose items each appear in more than $2 \%$ of our charity auction sample, are also in $S E L L E R_{i}$, with each dummy set equal to one if auction $i$ is associated with the corresponding seller.

Each seller chooses whether to donate a portion of the auction revenue to a charity. Information on charity status is contained in the vector DONATION, which includes dummy variables for a variety of donation levels. Additionally, sellers choose a vector of auction characteristics such as buy-it-now status, the length of the auction, and shipping fees; these are included in the vector $A U C T I O N_{i}$. While we are concerned that the entries in $A U_{C T I O N}$ may be correlated with the information in $\varepsilon_{i m}$, we retain these variables in most of our analysis as additional control variables. Finally, the number of bidders and the timing of the bidders' bids are endogenous variables which may be shifted by the values in $D^{\circ}{ }^{2} A T I O N_{i}$ and the other 
attributes of an auction. These endogenous variables may affect price as well, but they are excluded from our empirical model of auction prices.

In our empirical analysis we estimate the effects of $\alpha$, DONATION, AUCTION, and SELLER on prices and (separately) other endogenous variables discussed above. For example, we model the relationship between the closing price and auction characteristics as:

$$
\log \left(\text { PRICE }_{i m}\right)=\alpha_{m}+\text { DONATION }_{i} \beta+\text { AUCTION }_{i} \gamma+\operatorname{SELLER}_{i} \delta+\varepsilon_{i m} .
$$

The included variables within DONATION, AUCTION, and SELLER vary across specifications, and we refer the reader to the Tables for precise specifications. In equation (1), the parameter vector $\beta$ represents the full effect of a charity auction on price, even if this occurs through multiple mechanisms, such as shifts in bidder willingness to pay and changes to the number of bidders. The separate effects of charity donations on bid timing and bids per bidder are estimated as variants of equation (1) with $\log (P R I C E)$ replaced with the appropriate dependent variable. We adjust the model specification as necessary when the dependent variable takes discrete values. This additional analysis allows us to explain which attributes of bidder motivation and auction structure contribute to the value of $\beta$ estimated in equation (1). In the analysis below we exploit the matched structure of the data. Model parameters are identified through the differences within a match.

The analysis proceeds in three parts. We first examine how final prices are affected by a seller's decision to donate a share of the auction's proceeds. Second, we describe how the charity premium varies with the average price of products within a match. Third, we examine differences in the bid timing and frequency across charity and non-charity auctions.

\subsection{Is there a charity premium?}

To test whether eBay buyers pay more for items in charity auctions than in standard auctions, we estimate equation (1) while allowing for standard errors to be clustered within a match, $m$. We report the results in Table 3. In Column 1 we report the estimated price premium as the coefficient on CHARITY, a dummy variable entry of DONATION which equals one if any donation is made to charity and zero otherwise. In addition to the CHARITY dummy, we include controls for auction and seller characteristics which apply to both charity and standard auctions. We find that the closing prices in charity auctions are $9.5 \%$ greater than in standard auctions ( $p$ 
$<.001)$. The specification in Column 1 explains a very high proportion of the variation in the data (over 97\%), which we interpret as evidence that the match criteria worked well as the data were collected. In Column 2 we construct the dependent variable as $\log ($ PRICE +SHIPPING), which accounts for any differences in shipping charges between charity and non-charity sales. The estimated charity premium falls to $5.7 \%$, but this coefficient remains significant at $p<0.001$. The difference in charity premiums in Columns 1 and 2 can be attributed to the general tendency of non-charity sellers to set larger shipping fees than charity sellers. ${ }^{26}$ If bidders (rationally) account for inflated shipping charges, they depress their non-charity bids relative to charity bids, which inflates the estimated charity premium in Column $1 .{ }^{27}$ The analysis in Column 3 adds additional control variables for high volume sellers, and there is virtually no change in the estimated charity premium.

In Columns 4, 5, and 6 of Table 3 we investigate whether charity premiums are different in $10 \%$-share, $100 \%$-share, and other charity auctions. We specify three dummy variables in DONATION to indicate these cases, respectively: 10\%-SHARE, 100\%-SHARE, and MID-SHARE. In these regressions when shipping charges are added as a control (Column 4), the estimated coefficients on 10\%-SHARE, 100\%-SHARE, and MID-SHARE are $6.3 \%, 12.1 \%$, and $6.2 \%$, respectively. ${ }^{28}$ When we specify the full price as the dependent variable (Column 5), the estimated premiums are $4.7 \%, 7.0 \%$, and $2.5 \%$, respectively, and adding controls for high volume sellers (Column 6) yields estimates of 3.4\%, 7.9\%, and 2.5\%, respectively. In each regression, the coefficients on 10\%-SHARE and 100\%-SHARE are statistically different from zero at the $p<.05$ level, and in all but one case these coefficient are significant at the $p<.001$ level. Coefficients on MID-SHARE are significantly different from zero in Column 4 only.

Apparent differences in estimated charity premiums across auctions may be due to differences in the products for sale within each donation category. As noted in Section 4, the products in $10 \%$-share auctions have a substantially greater average value that those sold in

\footnotetext{
${ }^{26}$ This result follows from a fixed-effect regression of shipping charges on auction characteristics and CHARITY. When we permit DONATION to account for the size of the donation percentage, we find that this result is driven entirely by Giving Works auctions with $100 \%$ of revenue donated to charity. Other donation levels are not associated with significantly different shipping charges than their non-charity matched auctions.

${ }^{27}$ For further discussion of how sellers' shipping charges affect bidders' actions, see Hossain and Morgan (2006).

${ }^{28}$ We have repeated the analysis in Table 3 using true marginal donation rates instead of the sellers' donation rate choices. The coefficient estimates for marginal donation rates are slightly larger in magnitude for $10 \%$-share auctions and are otherwise nearly identical to those which use sellers' donation rate choices.
} 
100\%-share auctions. Furthermore as described in Section 3.2, bidders' benefits from auction revenue may have different impacts on prices in 10\%-share and $100 \%$-share auctions. These differences are investigated in the next sub-section.

To verify the robustness of our results, we repeat the analysis from Table 3's Column 5 with a variety of subsamples of our data. We present these additional results in Table 4, with the estimates from Column 5 in Table 3 reproduced in the first column of Table 4 to ease comparison. In Columns 2 and 3 of Table 4 we drop all buy-it-now sales, with Column 3 limited to true auctions which lasted exactly seven days. The coefficient estimates on the $10 \%-S H A R E$ and 100\%-SHARE dummy variables are largely unchanged, with some loss of significance due to the reduced number of observations. For Column 4 we add dummy variables for the day of the week on which the auction closed, plus dummy variables to indicate the closing time of a sale in one of six four-hour-long periods. The magnitude and significance of our charity coefficient estimates are virtually unchanged. In Column 5 we limit the observations to sellers with experience ratings in the middle $50 \%$ of all sellers in our sample. The coefficient on the $100 \%$ SHARE indicator is the only charity parameter which remains significantly different from zero, but the magnitudes of the point estimates do not change substantially relative to Column 1 .

The remaining models on Table 4 allow us to evaluate whether the error term in equation (1) is likely to contain information correlated with CHARITY, perhaps due to our sample selection rule, which conditions on successfully sold items. We first consider the possibility that sellers who know that they possess items with favorable characteristics (unobservable to the econometrician) will set greater opening prices. In Column 6 we show that including an auction's opening price as an additional control variable does not affect our charity coefficient estimates, and in fact the coefficient on the opening price is estimated precisely at nearly zero. ${ }^{29}$ We obtain similar results in models which include interactions between the opening price and dummy variables in DONATION. Next, we re-estimate the model with an auction's number of bidders included as a control, again to pick up unobserved auction attributes that attracted additional bidders and to provide preliminary evidence on whether our estimates in Table 3 are driven by differences in the numbers of bidders. In Column 7 of Table 4 we show that this

\footnotetext{
${ }^{29}$ The coefficient estimate is $7.9 \times 10^{-5}$ with a standard error of $5.8 \times 10^{-5}$. This result provides additional verification that our matching procedure worked well.
} 
additional control variable has virtually no effect on the estimated charity premiums. ${ }^{30}$ Finally, we restrict the sample to true auctions in which multiple bidders placed bids. This reduces the role of potentially idiosyncratically opening prices and provides an empirical basis for our conjecture that the data are drawn from thick markets in which conditioning on successful auctions is relatively harmless. Our results, which are reported in Column 8, show that the coefficient estimates on 10\%-SHARE and 100\%-SHARE are again unchanged.

\subsection{How does the charity premium vary with product value?}

In Sections 3.1 and 3.2 we argue that diminishing marginal utility from charity revenue can lead to falling charity premiums as the price increases. We investigate this issue in the data by separating the 10\%-share and 100\%-share charity auctions into four quartiles (each) based on the average price of the auctions within a match. ${ }^{31}$ For $10 \%$-share auctions, the prices at the $25^{\text {th }}$, $50^{\text {th }}$, and $75^{\text {th }}$ percentiles are $\$ 44, \$ 93$, and $\$ 146$, respectively. The $25^{\text {th }}, 50^{\text {th }}$, and $75^{\text {th }}$ percentile values of $100 \%$-share auctions are $\$ 18, \$ 28$, and $\$ 60$, respectively. Because the number of observations is more limited for auctions with MID-SHARE $=1$, the data on these auctions are split at the median, $\$ 38$. The premium in each quartile (or half) is then estimated by creating separate dummy variables for each donation level and price quantile.

We present the results of this analysis in Table 5. Columns 1 and 2 use $\log (P R I C E)$ and $\log (P R I C E+S H I P P I N G)$ as the dependent variable, respectively, and Columns 3 and 4 repeat the analysis with high volume seller dummies. Each specification shows similar results. For $100 \%$-share auctions, the premium is highest for the lowest-value items and falls steadily from the fourth to first (highest) quartile. ${ }^{32}$ For auctions with $M I D-S H A R E=1$, the premium is large

\footnotetext{
${ }^{30}$ The appropriate comparison here is to Column 2, as both Columns 2 and 7 are estimated without buy-it-now sales.

${ }^{31}$ We use the average price of all auctions within a match rather than the average price of all non-charity auctions. To see why this is desirable, consider a match in which there is one charity and one non-charity auction, and recall that the idiosyncratic component of demand $(\varepsilon)$ may be negatively correlated within a match. Then, matches in which the non-charity auction has an low value of $\varepsilon$ are more likely to appear in the lower quantiles of the price distribution, and the low value of the non-charity $\varepsilon$ will affect the estimated charity premium within the quantile. (Idiosyncratically large values of $\varepsilon$ in non-charity auctions are more likely to place a match in an upper quantile and result in under-estimating the charity premium there.) By including both the charity and non-charity observations in the average price calculation, we seek to average-out this effect.

${ }^{32}$ The magnitude of the premium in dollar terms does not change much over the range of the price distribution. Using the estimates from Column (2), the total premium on products at the $12.5^{\text {th }}, 37.5^{\text {th }}, 62.5^{\text {th }}$, and $87.5^{\text {th }}$ percentiles of non-charity prices in our sample would be $\$ 2.39, \$ 1.96, \$ 2.66$, and $\$ 2.13$, respectively for $100 \%$-share auctions.
} 
and statistically significant for low-value items and is statistically indistinguishable from zero for high-value items when $\log (P R I C E)$ is employed as the dependent variable. Both estimates are insignificant when $\log (P R I C E+$ SHIPPING $)$ is used, although the magnitude of the estimated premium for low-value items remains substantially greater. For 10\%-share auctions, no consistent pattern of decline can be observed. In these auctions the premiums tend to be larger in the first quartile than in the fourth, but the difference between the coefficients is not statistically significant.

The declining charity premiums support the notion of diminishing marginal values for charitable giving, and are broadly consistent with the participation model of Section 3.2. As the value of auctioned items increase, the resulting donations in 10\%-share and $100 \%$-share charity auctions become substantial without any additional charity premium. This is especially salient for $100 \%$-share auctions; at the $25^{\text {th }}$ percentile, $100 \%$-share auctions generate donations of approximately $\$ 18$, which is more than the donations generated by $10 \%$-share auctions at their $75^{\text {th }}$ percentile. Holding bidders' personal charitable donation levels $\left(d^{*}\right)$ fixed across different types of charity auctions, bidders reach these goals at lower prices in the $100 \%$-share auctions. It is therefore reasonable that the decline in the estimated charity premium appears at lower percentiles in 100\%-share auctions and the decline is more abrupt. Moreover, as prices and donation levels increase, we expect that bidders become more concerned about the quality of the match between the seller's charitable interest and their own. Maintaining a substantial charity premium for high-value items may be impossible when the dollar value of the premium exceeds the bidder's utility gain from switching to an out-of-pocket donation to a personally favored charity.

The pattern of declining charity premiums in $100 \%$-share auctions provides a final piece of useful evidence. An alternative explanation for the estimated charity premiums is that these premiums do not reflect charitable intent at all, and instead they proxy for unobserved product or seller quality. For example, bidders may have greater confidence that a used item sold through a charity auction works well, or that a charity item's seller is unlikely to offer poor service after the auction closes. If, however, unobserved seller quality is the only factor behind charity premiums, premiums would likely appear throughout the distribution of auction prices. An unobservedquality perspective of the declining premiums requires an explanation that this issue is very important for low-value items but not high-value products. While possible, this strikes us as 
unlikely. Evidence below on bid timing also supports the view that the premiums are not entirely due to unobserved product quality differences. In considering the effects of inferred seller quality on auction prices, we note that our empirical models include controls for sellers' ratings and experience.

\subsection{Bid timing and frequency}

In Section 3.3 we argue that a bidder's incentive to delay bidding could be weakened in a charity auction if he receives positive utility from the donations of other bidders. In terms of the static bidding model of Section 3.1, this is when $\lambda>0$. We investigate this issue in two ways. First, we examine the lag between the time of a bidder's final bid and the auction ending time. Second, we test whether shifts in charity bid timing are associated with more aggressive behavior by naive bidders.

Our analysis of the duration (in days) between bids and an auction's end time involves an empirical model similar to equation (1) but with measures of bidder experience (functions of their eBay feedback scores) as additional control variables. ${ }^{33}$ We exclude buy-it-now sales from the analysis, and we continue to employ match-specific fixed effects and report standard errors that are clustered by match. In this context, the match dummies may capture the likelihood of bidders colluding or bidding incrementally for a particular product. In eliminating buy-it-now sales the average auction duration increases from 4.3 to 5.1 days for non-charity listings and from 6.1 to 6.4 days for Giving Works auctions. The differences in auction duration are nearly eliminated if we also drop the auctions that ran for three days or fewer, and eliminating these observations has no effect on the results described below.

We begin by estimating the timing of final bids for all bidders observed in our matched sample. These results are reported in Column 1 of Table 6. In this specification, individuals' maximum bids in 100\%-share auctions occur, on average, 0.43 days earlier than in the matched non-charity auctions. This result is significant at $p<.001$. Final bids arrive 0.28 days earlier in auctions with MID-SHARE $=1$ than standard auctions, although this result is marginally significant $(p=.105)$. We find no significant change in bid timing for $10 \%$-share auctions, which suggests that in these auctions the donations of other bidders may not be large enough to

\footnotetext{
${ }^{33}$ Ariely, Ockenfels, and Roth (2005) and Ockenfels and Roth (2003) find that sniping is more common by more experienced bidders.
} 
warrant shifting bid times. When we repeat the analysis on a subsample of bidders who bid exactly once, the estimated time differences between charity and non-charity bids are slightly larger.

We consider next whether the shift in bid timing could be caused by bidder selection across charity and non-charity auctions. It may be true that $\lambda$ has no role in influencing bid timing, and charity bidders possess a non-strategic preference to bid earlier. We test this alternative explanation by constructing a subsample of bids placed by bidders who were active in both charity and non-charity auctions within a matched set of sales. For each bidder-product combination we create a new fixed effect and estimate whether bidding occurs earlier in the charity auctions. Results are reported in Column 2 of Table 6 . We find that final bids in 100\%share auctions again occur about half a day earlier than in the matched standard auctions $(p$ $<.01)$. Thus, differences in bidder preferences fail to explain the prevalence of early bids in charity auctions, which supports our interpretation that bidding occurs earlier because of the public goods nature of auction revenue.

Most of the existing research on bid timing in online auctions has focused on literal lastminute (and last-second) bidding. ${ }^{34}$ Our data are insufficient for this analysis, as there are too few matched auctions with variation in discrete measures of bid timing in the final moments of an auction. In a related working paper (Elfenbein and McManus, 2007) we employ a different data set and ask whether charity auctions differ significantly from non-charity auctions in the incidence of last-minute bidding or "sniping." We corroborate the results in the present paper by finding that bidding immediately before the end of an auction is significantly less common in charity auctions and that the effects are particularly pronounced in $100 \%$-share and mid-share auctions.

We now examine the effects of bid timing choices. In Ely and Hossain (2006), squatting results in greater revenue because naive bidders who arrive late at the auction need to bid more aggressively to win. Therefore, if strategic bidders in charity auctions shift forward their bid times in order to drive up closing prices, we should observe incremental bidding more frequently in charity auctions. In contrast, if strategic (one-time) bidders accelerate their bid timing with no

\footnotetext{
34 The recent research of Ely and Hossain (2006), however, suggests that late bidding does not need to occur in the last minutes of an auction to be worthwhile.
} 
effect on others' bids, then the pattern of bidding would not support the public goods interpretation of charity bid timing.

We study this aspect of charity bid timing by creating a measure of incremental bidding. Within each auction, we count the number of bids each bidder submits and identify a bidder as incremental if he places multiple bids. ${ }^{35}$ This definition is necessarily ad hoc, since it is impossible for us to discern the difference between actual incremental bidders and strategic bidders who may revise their bids with the arrival of new information. Bidders, indexed by $j$, have their bidding status for auction $i$ recorded in the indicator variable $I N C R_{i j}$. We set $I N C R_{i j}=$ 1 if the bidder bids two or more times, and $I N C R_{i j}=0$ otherwise. $38 \%$ of bidders have $I N C R_{i j}=$ 1 and at least one incremental bidder appears in $79 \%$ of all auctions.

For every bidder in each true auction, we first estimate the probability that $I N C R_{i j}=1$ with a probit model. In this model we include the same set of auction, seller, and bidder controls as in the analysis of bid timing, including a full set of match-specific fixed effects. Results are reported as marginal probabilities in Column 3 of Table 6. We find that an individual bidder's probability of $I N C R_{i j}=1$ is 3.7 percentage points greater in $100 \%$-share auctions than noncharity auctions $(p=0.06)$. This represents a $10 \%$ increase in the probability of a bidder submitting multiple bids relative to the sample average among non-charity auctions. ${ }^{36}$ We interpret this result as an increase in (naive) bidder aggressiveness following early bidding by other bidders. ${ }^{37}$ Incremental bidding is no more common in charity auctions with less than $100 \%$ of revenue donated than in non-charity auctions.

Finally, we estimate whether an auction's winning bidder is likely to have submitted multiple bids. In Column 4 of Table 6 we report a significantly increased probability that a $100 \%$-share auction is won by bidder with $I N C R_{i j}=1$. The marginal effect of 14.1 percentage

\footnotetext{
${ }^{35}$ More precisely, this is a measure of whether an incremental bidder reveals himself as such. "Unprovoked" naive bidders will bid only once in an auction when all other bidders snipe.

${ }^{36}$ This bidder-level analysis may be too conservative in that once one bidder submits a sequence of incremental bids, the (potential) incremental bidders who begin bidding later are less likely to require multiple bids to reach their maximum willingness to pay. We confirm this intuition at the auction level by estimating the probability that at least one bidder submits multiple bids. Among the auctions included in the analysis, we find that charity auctions are $45 \%$ more likely to include an incremental bidder.

${ }^{37}$ An alternative explanation is that incremental bidding is observed more frequently in charity auctions simply because these auctions are favored by naive bidders. If this is true and strategic bidders have $\lambda=0$, then we would expect strategic bidders to delay their charity bids rather than placing them earlier. Thus, this alternative explanation is also compatible with a public goods interpretation of auction revenue.
} 
points represents a substantial increase in the probability of this event, as the sample mean for incremental bidders winning non-charity auctions is $44 \%$ among the included observations. This supports the interpretation that early bidding occurs in charity auctions because of the public goods effect from auction revenue. Early bidding is beneficial to strategic bidders when this behavior induces other bidders to pay more for an item for sale.

\section{Conclusion}

We study whether consumers will pay higher prices for products linked to charities. This research is relevant to considerations of whether for-profit firms' socially responsible behavior can be motivated by conventional material objectives. Most past research on this topic has not addressed these issues with field data on what consumers will actually pay for charity-linked items. This paper fills this gap in the empirical literature with data that cover a wide variety of products and prices. Organizing a field experiment to recreate the $100 \%$-share data alone would require approximately $\$ 32,300$ to purchase the 429 objects to be sold in these charity auctions. ${ }^{38}$

We assemble a novel data set by collecting extensive information on charity and noncharity auctions on eBay. Each charity auction in the data is matched to one or more non-charity auctions of a virtually identical product save for the charity component. After controlling for remaining differences in auction format and seller characteristics within matched groups of products, we find that auctions with $10 \%$ of revenue dedicated to charity have full prices that are $5 \%$ higher than in non-charity auctions. This fits fairly well with the model of charity auction participation we develop in Section 3.2. In auctions with $100 \%$ of revenue dedicated to charity, full prices are $7 \%$ higher than in non-charity auctions. Interestingly, these economically significant premiums are present even though the empirical setting is one in which consumers are unlikely to enter the market with the intention to find a donation opportunity and the charities chosen by sellers vary widely in scope and appeal.

Although the premium in 10\%-share auctions we estimate is not large enough alone to increase seller profit, it is inappropriate to draw the conclusion that charity links should, in general, be avoided. If, for example, a firm combines a charity program with a strong marketing campaign, it may experience a sufficient increase in demand to justify the program as profit-

\footnotetext{
${ }^{38} \mathrm{We}$ assume here that each item could be purchased at its average non-charity price plus shipping charges. It may be possible to obtain and sell the non-charity control objects with no net expense except shipping costs.
} 
enhancing. Additionally, if firms feel compelled to make donations, whether for reasons of altruism, political expediency, or brand-building, it could be appealing to have consumers absorb even a fraction of this expense, as they do in the $10 \%$-share premium that we estimate. Finally, tax considerations may also affect firms' decisions to incorporate charity links in product sales because these donations often may be deducted from a firm's tax liability.

While we interpret our results as primarily useful in understanding the strategies of forprofit firms, our work in this area may also inform some fund-raising strategies of non-profit organizations. Consider the merchandise offered in art museum gift shops, in catalogs and online stores for the National Geographic Society or Smithsonian Institute, and even Girl Scout cookies. In these examples, the nonprofit group needs to decide whether to incur direct costs to acquire a product that it would then sell to raise money for its mission. If increased demand does not allow a price premium above the competitive price for the same products, then fundraising efforts may be directed more productively to other strategies.

An additional important result is that the charity premiums typically decrease in the closing price of the auction. This could reflect two factors. First, consumers may have diminishing marginal utility in the size of a donation, as is frequently assumed in voluntary donation models. Second, consumers may be willing to support a seller's designated charity when the premium value is relatively small, but unwilling to a pay a large price premium if they believe that a similarly large donation to their own favored charities would provide greater utility. The result that premiums are greater for lower-value items appears consistent with common practice in CRM and charitable fundraising. In cause-related marking strategies, for example, we expect to see firms make revenue or profit donation pledges for products that are a small portion of consumers' budgets, ${ }^{39}$ while eschewing these pledges for higher-priced items. In the case of charitable fundraising, we conjecture that it is reasonable to see low-price items marketed widely, including to potential customers who may value the charity minimally, ${ }^{40}$ while charity auctions for high-value items are most successful when the bidders have a strong personal attachment to the charitable cause (e.g., their own child's school or a favorite museum).

\footnotetext{
${ }^{39}$ Consider the retail items mentioned in this paper's Introduction, such as Starbucks coffee and Ben and Jerry's ice cream. An interesting exception to this pattern may be the success of the hybrid-powered Toyota Prius.

${ }^{40}$ For example, it is common for grade schools to fund-raise through door-to-door sales of products like candy, gift wrapping paper, and magazines.
} 
Finally, we note that the charity auctions we study have significantly earlier bidding than their matched non-charity counterparts. This is consistent with the posited public goods nature of charity auction revenue, which benefits even the losing bidders in an auction. To confirm that these timing results reveal consumers' preferences, additional research is needed to further describe the strategic motivations behind bid timing choices. Behavioral explanations, such as consumer distaste for opportunistic sniping in charity settings, should be considered as well.

We view the present paper as one step in demonstrating that product sales can increase total revenue for a charity or other public good. Yet the results here are not sufficient to achieve this larger goal. Even if consumers purchase charity-linked products at a premium because they care about the charitable cause, total revenue for the cause may not change. If these wellintentioned consumers simply reduce their own direct donations after purchasing at a premium, then an apparently successful product program would provide no net gain. To evaluate these issues, further data are required to analyze how consumers substitute between charity-linked products and donations, and how product sales attract consumers who would not otherwise make a direct donation to a charity. 


\section{A1. Appendix: The matching process}

In this appendix we describe how we identified and matched the eBay auctions in our data. Although there are thousands of active eBay Giving Works auctions at any moment, relatively few of them are useful within a low-cost and precise matching process. For example, there are many pieces of original artwork listed as Giving Works auctions, but in general it is impossible to match them to identical non-charity items. To search for potentially useful charity auctions in a low cost way, we divided the main eBay product categories among ourselves and two research assistants (RAs). Product categories include classifications like "Consumer Electronics," "Cameras and Photo," and "DVDs and Movies." Each person was instructed to monitor a group of product categories and search for charity auctions that might be matched to simultaneouslyopen non-charity auctions. ${ }^{41}$ In practice, this meant looking for products that were new or nearly new and were not often bundled with many accessories. For example, it was easy to match DVDs because it is standard on eBay to describe DVD condition with a few clear phrases ("new and sealed," "viewed once," "no scratches") and to provide a UPC code that identifies the DVD's edition, screen format, and other details. On the other hand, while there is a large market for film cameras on eBay, it is generally difficult to find a pair of cameras that match in body model; lens model; the condition of the body and lens; and the presence of instruction manuals, cases, straps, and other accessories.

In matching a Giving Works auction to a non-charity auction, we considered only the physical characteristics of the product for sale to create an acceptable match. This means that within a "match" there are other attributes of the auction that not identical. Sellers' characteristics such as reputation score and feedback rating are not matched. Similarly, neither the appearance of an auction listing (amounts of text and pictures) nor its ending time is matched. Including even one of these characteristics in the matching process would substantially reduce the amount of usable data. Instead, we record information on these auction details and include them as control variables in our empirical analysis. In this way, we are able to account for some variation in prices within our matches through the influence of these variables.

Our matching process covered eBay listings that closed between March and December 2006. We identified the auctions in two ways. First, we searched eBay's listings of currently-

\footnotetext{
${ }^{41}$ There were some categories, like Clothing and Jewelry, which we omitted from most searches because we anticipated that our undergraduate RAs would be insufficiently familiar with the items to accurately identify which charity auctions would be worth pursuing.
} 
open Giving Works auctions, and then after finding a potentially promising charity auction we would search eBay non-charity listings. Second, we used eBay's Marketplace Research program to search eBay's archived data for matching charity and non-charity auctions. About half of our data come from each search method. Within each search process, we recorded the auction identification numbers of up to five matching non-charity auctions that had closing times within five days of the charity auction's ending time. We were unable to use an automated program to generate matched data because important product characteristic information is often conveyed through pictures and through pieces of text that are particular to specific categories.

Our procedures, as executed by research assistants and ourselves, returned a set of 5,458 auctions organized around 1,568 charity auctions. We visually inspected each auction associated with a potential match to insure that all auctions in our sample met the criterion of identical product characteristics. These inspections lead us to reject 1,300 proposed matches between charity and non-charity items, and reduced the set of observations to 3,642 auctions including 1,049 Giving Works auctions. See Table A1 for examples of auctions brought to us as potential matches that we rejected as for being insufficiently similar in product characteristics.

We further reduced the set of matched auctions by eliminating items that closed at very low prices. We drop all auctions for which the final price is $\$ 2$ or less, and we exclude all auctions within a matched cluster if the average price across the set of observations is less than \$5 before shipping charges are included. Given our empirical approach, described in Section 5, these observations may yield deceptively large percentage charity premiums despite the premium having a small absolute magnitude. After dropping these items with low closing prices, we are left 2,437 total auctions organized around 723 charity items. These are the data with which we perform our empirical analysis. 


\section{References}

Andreoni, James (2006), "Philanthropy" in S-C. Kolm and J. Mercier Ythier, eds., Handbook of Giving, Reciprocity and Altruism, Amsterdam: North Holland, 2006, pp. 1201-1269.

Ariely, Dan; Ockenfels, Axel; and Roth, Alvin (2005), “An Experimental Analysis of Ending Rules in Internet Auctions," RAND Journal of Economics, vol. 36(4), pp. 890-907.

Arora, Neeraj and Henderson, Ty (2007), "Embedded Premium Promotion: Why It Works and How to Make It More Effective,” Marketing Science vol. 26(4), pp. 514-531.

Bagnoli, Mark and Watts, Susan G. (2003), "Selling to Socially Responsible Consumers: Competition and the Private Provision of Public Goods," Journal of Economics \& Management Strategy, vol. 12(3), pp. 419-445.

Bajari, Patrick and Hortacsu, Ali (2003), “The Winner's Curse, Reserve Prices and Endogenous Entry: Empirical Insights from eBay Auctions," RAND Journal of Economics, vol. 34(2), pp. 329-355.

Bajari, Patrick and Hortacsu, Ali (2004), "Empirical Insights from Internet Auctions: A Survey," Journal of Economic Literature, vol. 42(2), pp. 457-486.

Baron, David P. (2001), "Private Politics, Corporate Social Responsibility, and Integrated Strategy," Journal of Economics \& Management Strategy, vol. 10(1), pp. 7-45.

Baron, David P. (2007), “Corporate Social Responsibility and Social Entrepreneurship,” Journal of Economics \& Management Strategy, vol. 16(3), pp. 683-717.

Brammer, Stephen, Millington, Andrew, and Rayton, Bruce (2007), "The Contribution of Corporate Social Responsibility to Organisational Commitment," International Journal of Human Resources, forthcoming.

Carpenter, Jeffrey; Holmes, Jessica; and Matthews, Peter Hans (2005), “Charity Auctions: A Field Experiment," Middlebury College working paper.

Chua, Clare and Berger, Ida (2006), "Charity Auctions on the Internet: An Exploratory Study," Ryerson University working paper.

Davis, Douglas; Razzolini, Laura; Reilly, Robert; and Wilson, Bart (2003), "Raising Revenue for Charity: Auctions versus Lotteries," Virginia Commonwealth University working paper.

Elfenbein, Daniel and McManus, Brian (2007), "Last Minute Bidding in eBay Charity Auctions," Washington University Olin School of Business working paper. 
Ely, Jeffrey and Hossain, Tanjim (2006), "Sniping and Squatting in Auction Markets," Northwestern University working paper.

Engers, Maxim and McManus, Brian (2007), "Charity Auctions," International Economic Review vol. 48(3), pp. 953-994.

Friedman, Milton, "The Social Responsibility of Business is to Increase its Profits," The New York Times Magazine, September 13, 1970.

Goeree, Jacob; Maasland, Emiel; Onderstal, Sander; and Turner, John L. (2005), "How (Not) to Raise Money,” Journal of Political Economy, vol. 113 (4), pp. 897-926.

Haley, Usha C.V. (1991), "Corporate contributions as managerial masques: reframing corporate contributions as strategies to influence society.” Journal of Management Studies, vol. 28 (5), pp. 485-509.

Hiscox, Michael J. and Smyth, Nicholas F. (2007), "Is There Consumer Demand for Improved Labor Standards? Evidence from Field Experiments in Social Product Labeling," Harvard University Working Paper.

Hossain, Tanjim and Morgan, John (2006), "...Plus Shipping and Handling: Revenue (Non) Equivalence in Field Experiments on eBay“, Advances in Economic Analysis \& Policy: Vol. 6: No. 2, Article 3

Issac, R. Mark and Schnier, Kurt (2005), "Silent Auctions in the Field and in the Laboratory," Economic Inquiry, vol. 43(4), pp. 715-733.

Kotchen, Matthew J. (2006), "Green Markets and Private Provision of Public Goods," Journal of Political Economy, vol. 114(4), pp. 846-834.

Landry, Craig E.; Lange, Andreas; List, John A; Price, Michael K.; and Rupp, Nicholas G. (2006), "Toward an Understanding of the Economics of Charity: Evidence from a Field Experiment," Quarterly Journal of Economics vol. 121(2), pp. 747-82.

Lichtenstein, Donald R.; Drumwright, Minette M.; and Braig, Bridgitte M. (2004), "The Effect of Corporate Social Responsibility on Customer Donations to Corporate-Supported Nonprofits." Journal of Marketing vol. 68 (October), pp. 16-32.

Margolis, Joshua D.; Elfenbein, Hillary A.; and Walsh, James P. (2007), "Does It Pay To Be Good? A Meta-Analysis and Redirection of Research on Corporate Social and Financial Performance," Harvard University working paper. 
Meyer, Harvey (1999). "When the Cause is Just," Journal of Business Strategy vol. 20(6), pp. 27-32.

Mohr, Lois A., and Webb, Deborah J. (2005), "The Effects of Corporate Social Responsibility and Price on Consumer Responses," Journal of Consumer Affairs vol. 39(1), pp.121-147.

Morgan, John (2000), "Financing Public Goods by Means of Lotteries," Review of Economic Studies vol. 67, pp. 761-784.

Morgan, John and Sefton, Martin (2000), "Funding Public Goods with Lotteries," Review of Economic Studies vol. 67, pp. 785-810.

Navarro, Peter (1988), "Why do corporations give to charity?” Journal of Business vol. 61(1), pp. 65-93.

Ockenfels, Axel and Roth, Alvin E. (2003), "Late and Multiple Bidding in Second-Price Auctions: Theory and Evidence Concerning Different Ending Rules for an Auction," forthcoming Games and Economic Behavior.

Onderstal, AM and Schram, Arthur (2006), "Bidding to Give: An Experimental Comparison of Auctions for Charity," Universiteit van Amsterdam working paper.

Polishchuk, Leonid and Firsov, Evgeny (2005), "Cause-Related Marketing: An Economic Analysis," New Economic School working paper.

Popkowski Leszczyc, Peter T. L. and Rothkopf, Michael H. (2006), "Charitable Intent and Bidding in Charity Auctions," University of Alberta working paper.

Roth, Alvin E. and Ockenfels, Axel (2002), "Last-Minute Bidding and the Rules for Ending Second-Price Auctions: Evidence from eBay and Amazon Auctions on the Internet," American Economic Review vol. 92 (4), pp.1093-1103.

Sen, Sankar and Bhattacharya, C.B. (2001), "Does Doing Good Always Lead to Doing Better? Consumer Reactions to Corporate Social Responsibility." Journal of Marketing Research vol. 38 (May), pp. 225-243.

Strahilevitz, Michal and Myers, John G. (1998), "Donations to Charity as Purchase Incentives: How Well They Work May Depend on What You are Trying to Sell," Journal of Consumer Research, vol. 24 (4), pp. 434-446.

Varadarajan, P Rajan and Menon, Anil (1988), "Cause-Related Marketing: A Coalignment of Marketing Strategy and Corporate Philanthropy," Journal of Marketing vol. 52 (3), pp. $58-74$. 
Figure 1

Bounds on the Charity Premium

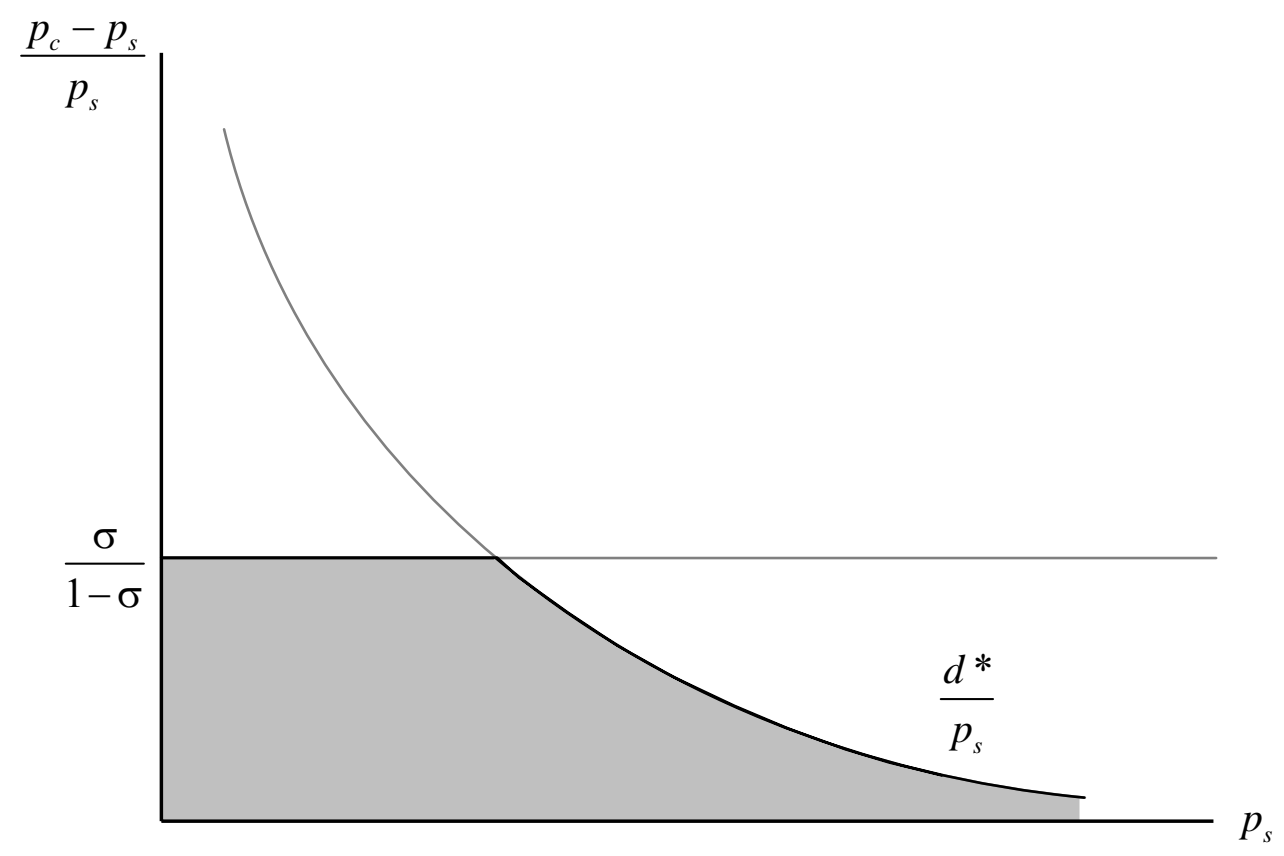

Notes: The price in a standard auction is $p_{\mathrm{s}}$, and the price in a charity auction is $p_{\mathrm{c}}$. The share of $p_{\mathrm{c}}$ donated to charity is $\sigma$, and $d^{*}$ is a consumer's optimal direct donation. When $\sigma<1$ in the participation model of Section 3.2, a charity-minded agent is willing to pay a charity premium in the Figure's shared area for varying values of $p_{\mathrm{s}}$. When $\sigma=1$ the range of acceptable charity premiums is the area beneath the curve $d^{*} / p_{s}$ alone. 
Figure 2

Distribution of Charity Premiums

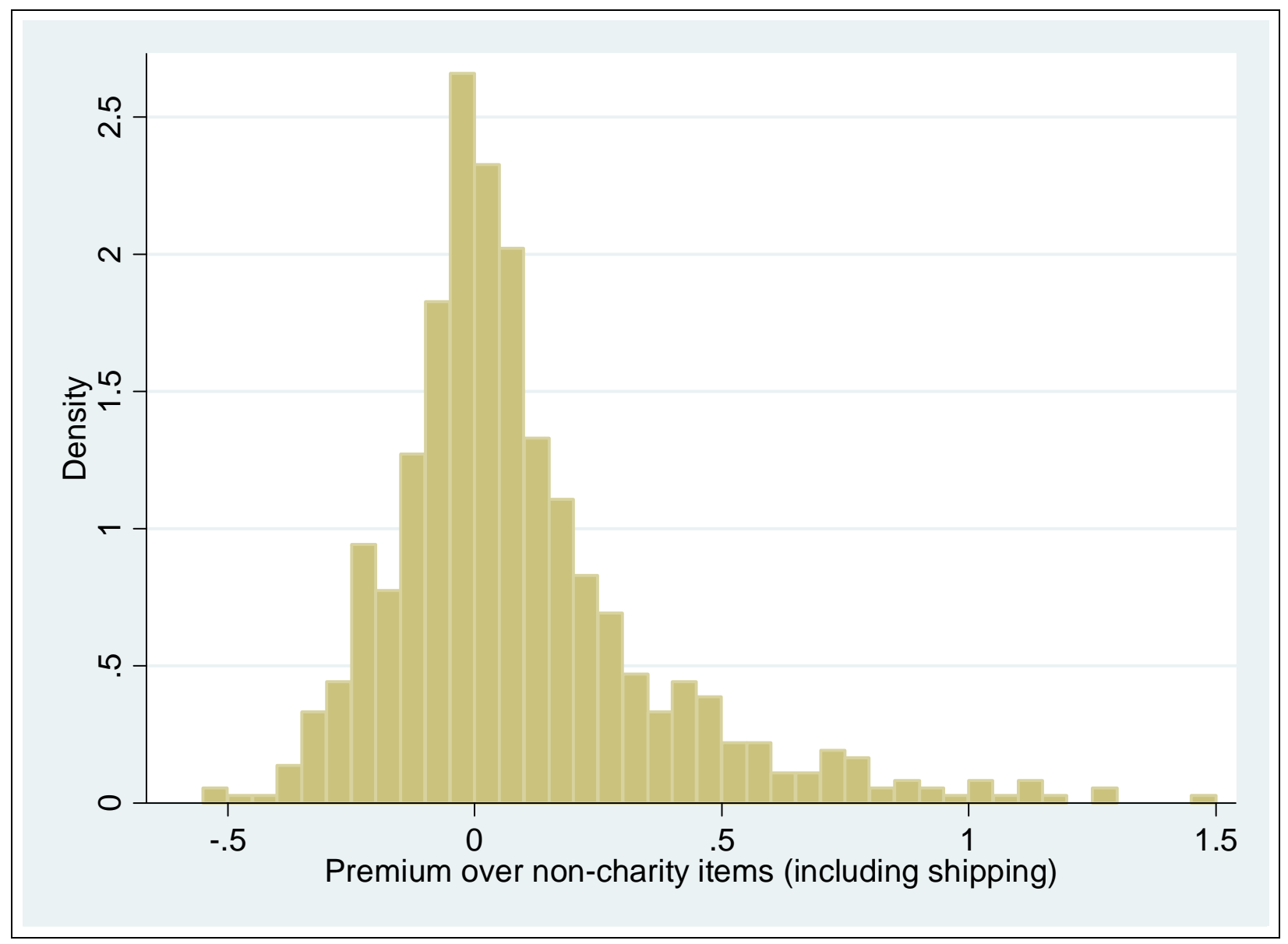

Notes: Charity premium is calculated as the fractional difference between the price of the charity item and the average price of all non-charity items in the matched set. 
Table 1

Summary Statistics of Matched Sample of eBay Giving Works Auctions

\begin{tabular}{|c|c|c|c|c|c|c|}
\hline \multicolumn{7}{|c|}{ Panel A: All Matched Auctions } \\
\hline & Obs & Mean & Median & Std Dev & Min & Max \\
\hline Sale Price (\$) & 2437 & 88.23 & 41.00 & 139.22 & 2.00 & $1,375.00$ \\
\hline Sale Price inc. shipping $(\$)$ & 2437 & 97.63 & 49.00 & 142.92 & 5.89 & $1,405.00$ \\
\hline Shipping (\$) & 2437 & 9.40 & 7.99 & 7.30 & 0 & 67.50 \\
\hline Length of Auction (days) & 2437 & 5.66 & 7 & 2.63 & .001 & 10 \\
\hline Buy It Now (dummy) & 2437 & .21 & 0 & .41 & 0 & 1 \\
\hline Power Seller (dummy) & 2437 & .35 & 0 & .48 & 0 & 1 \\
\hline Seller Rating & 2437 & 5596 & 374 & 20619 & 1 & 309979 \\
\hline Seller Positive Ratings (\%) & 2437 & 99.4 & 99.8 & 1.4 & 75 & 100 \\
\hline Number of Bids & 2264 & 8.83 & 7 & 7.82 & 1 & 57 \\
\hline Unique Bidders & 2236 & 4.45 & 4 & 3.31 & 1 & 21 \\
\hline \multicolumn{7}{|c|}{ Panel B: Charity Auctions Only } \\
\hline & Obs & Mean & Median & Std Dev & Min & $\operatorname{Max}$ \\
\hline Sale Price $(\$)$ & 723 & 93.65 & 41.56 & 143.05 & 6.51 & 1371.01 \\
\hline Sale Price inc. shipping (\$) & 723 & 102.38 & 50.95 & 145.77 & 8.11 & 1393.01 \\
\hline Shipping (\$) & 723 & 8.72 & 7.00 & 6.77 & 0 & 55.00 \\
\hline Length of Auction (days) & 723 & 6.10 & 7 & 2.10 & .014 & 10 \\
\hline Buy It Now (dummy) & 723 & .10 & 0 & .29 & 0 & 1 \\
\hline Power Seller (dummy) & 723 & .40 & 0 & .49 & 0 & 1 \\
\hline Seller Rating & 723 & 3055 & 275 & 10697 & 0 & 139266 \\
\hline Seller Positive Ratings (\%) & 723 & 99.4 & 99.8 & 1.4 & 83.3 & 100 \\
\hline Number of Bids & 718 & 9.22 & 8 & 7.52 & 1 & 57 \\
\hline Unique Bidders & 710 & 4.62 & 4 & 3.10 & 1 & 21 \\
\hline Donation percentage (\%) & 723 & 66.1 & 100 & 42.0 & 10 & 100 \\
\hline Marginal donation percent $(\%)$ & 723 & 64.7 & 100 & 44.0 & 10 & 100 \\
\hline Don. percent $x$ Sale Price $(\$)$ & 723 & 49.20 & 20.50 & 99.66 & 1.00 & 1058.83 \\
\hline Total Donation, after fees $(\$)$ & 723 & 43.42 & 16.80 & 93.11 & 3.32 & 1025.12 \\
\hline \multicolumn{7}{|c|}{ Panel C: Non-Charity Matches Only } \\
\hline & Obs & Mean & Median & Std Dev & Min & $\operatorname{Max}$ \\
\hline Sale Price $(\$)$ & 1714 & 85.95 & 41.00 & 137.55 & 2 & 1375.00 \\
\hline Sale Price inc. shipping $(\$)$ & 1714 & 95.63 & 48.00 & 141.69 & 5.89 & 1405 \\
\hline Shipping (\$) & 1714 & 9.68 & 8.00 & 7.50 & 0 & 67.5 \\
\hline Length of Auction (days) & 1714 & 4.31 & 5 & 2.65 & .001 & 10 \\
\hline Buy It Now (dummy) & 1714 & .26 & 0 & .44 & 0 & 1 \\
\hline Power Seller (dummy) & 1714 & .33 & 0 & .47 & 0 & 1 \\
\hline Seller Rating & 1714 & 6665 & 402 & 23505 & 1 & 309979 \\
\hline Seller Positive Ratings (\%) & 1714 & 99.4 & 99.8 & 1.5 & 75 & 100 \\
\hline Number of Bids & 1546 & 8.66 & 7 & 7.95 & 1 & 54 \\
\hline Unique Bidders & 1526 & 4.37 & 4 & 3.40 & 1 & 20 \\
\hline \multicolumn{7}{|c|}{ Panel D: Charity Premiums } \\
\hline Premium over non-charity items & 723 & .171 & .046 & .491 & -.583 & 6.750 \\
\hline $\begin{array}{l}\text { Premium over non-charity items } \\
\text { including shipping }\end{array}$ & 723 & .088 & .033 & .275 & -.516 & 1.483 \\
\hline
\end{tabular}

Notes: The sample includes only auctions that resulted in a sale and lasted 10 days or fewer. Some eBay auctions do not result in sales because reserve prices are not met or the seller decides to remove or re-list the item. The "Buy It Now" dummy equals 1 if the auction ended at the seller's specified buy-it-now price. The "Power Seller" dummy equals 1 if eBay classified the seller as a power seller. Panel D provide the calculations of the ratio of charity auction prices to the average prices of the matched auctions (excluding the charity items). 
Table 2

A Sampling of Charities in the Data

\begin{tabular}{lc}
\hline \hline Charity name & $\begin{array}{c}\text { Auctions } \\
\text { in sample }\end{array}$ \\
\hline 21st Century CARES & 1 \\
3d\&i & 8 \\
9/11 Families Give Back Fund & 1 \\
A Gift for the Future Children's Fund & 3 \\
A Glimmer of Hope & 2 \\
A Home Within & 1 \\
AIDS Research Consortium of Atlanta & 1 \\
All Children's Assistance Fund & 2 \\
ASPCA: American Society for the Prevention of Cruelty to Animals & 5 \\
Ability First & 1 \\
Abused and Homeless Children's Refuge/Alternative House & 1 \\
Adams Elementary School PTA & 2 \\
Adirondack Scholarship Foundation, Inc. & 1 \\
Admiral Jeremiah Denton Foundation & 1 \\
Adopted By Christ Ministries & 2 \\
Advocates for Children & 1 \\
African Well Fund & 1 \\
After-School All-Stars & 1 \\
Alex's Lemonade Stand Foundation & 1 \\
All Faiths Pantry & 2 \\
Alley Cat Allies & 1 \\
Alley Cat Rescue & 1 \\
Alzheimer's Assn, Central New York Chapter & 1 \\
Alzheimer's Assn, Hudson Valley/Rockland/Westchester NY Chapter & 1 \\
AmeriCares Foundation Inc. & 3 \\
American Breast Cancer Foundation & 1 \\
American Cancer Society & 2 \\
American Cancer Society - California Division & 1 \\
American Cancer Society, Eastern Division, Inc. & 2 \\
American Diabetes Association & 2 \\
American Heart Association National Center & 2 \\
American India Foundation & 2 \\
American Numismatic Association & 1 \\
American Red Cross & 1 \\
American Red Cross - Fresno Madera Chapter - Fresno, CA & 1 \\
American Red Cross - Northeast Georgia Chapter & 3 \\
American Red Cross - San Francisco Bay Area Chapter & 1 \\
American Red Cross - Oregon Pacific Chapter - Eugene, OR & 2 \\
American Tortoise Rescue & 1 \\
Amnesty International & 1 \\
\hline \hline & 2 \\
\hline
\end{tabular}

Notes: There are 330 charities in our data. This table lists the first 40 as organized alphabetically by charity name. 
Table 3

Charity Premium Estimates

\begin{tabular}{|c|c|c|c|c|c|c|}
\hline Dependent Variable: & Log Price & $\begin{array}{c}\text { Log (Price }+ \\
\text { Shipping) }\end{array}$ & $\begin{array}{c}\text { Log (Price }+ \\
\text { Shipping) }\end{array}$ & Log Price & $\begin{array}{c}\text { Log (Price }+ \\
\text { Shipping) }\end{array}$ & $\begin{array}{c}\text { Log (Price }+ \\
\text { Shipping) }\end{array}$ \\
\hline Column: & (1) & (2) & (3) & (4) & (5) & (6) \\
\hline \multicolumn{7}{|l|}{ Charity Variables } \\
\hline CHARITY & $* * * .095[.012]$ & $* * * .057[.009]$ & $* * * .055[.009]$ & & & \\
\hline 10\%-SHARE & & & & $* * * .063[.017]$ & $* * * .047[.014]$ & $* .034[.016]$ \\
\hline $100 \%$-SHARE & & & & $* * * .121[.016]$ & $* * * .070[.012]$ & $* * * .079[.014]$ \\
\hline MID-SHARE & & & & $* .062[.029]$ & $.025[.024]$ & $.025[.024]$ \\
\hline \multicolumn{7}{|l|}{ Auction \& Seller Characteristics } \\
\hline Log(Seller Rating) & $.005[.004]$ & $* .006[.003]$ & ${ }^{\dagger} .005[.003]$ & $.005[.004]$ & $* .006[.003]$ & ${ }^{\dagger} .006[.003]$ \\
\hline Seller Positive Ratings $(\%)=100$ & $.034[.024]$ & $.015[.018]$ & $.012[.019]$ & $.032[.024]$ & $.014[.019]$ & $.009[.018]$ \\
\hline Seller Positive Ratings $(\%) \in[99.5,100)$ & $.041[.026]$ & $.010[.020]$ & $.006[.020]$ & $.037[.026]$ & $.010[.020]$ & $.001[.020]$ \\
\hline Seller Positive Ratings $(\%) \in[99.0,99.5)$ & ${ }^{\dagger} .048[.028]$ & $.005[.021]$ & $.000[.022]$ & $.039[.028]$ & $.002[.022]$ & $-.003[.022]$ \\
\hline Seller Positive Ratings $(\%) \in[98.0,99.0)$ & $.011[.032]$ & $-.001[.023]$ & $-.006[.023]$ & $.011[.032]$ & $-.000[.023]$ & $-.007[.023]$ \\
\hline Power Seller dummy & $.021[.014]$ & ${ }^{\dagger} .018[.011]$ & ${ }^{\dagger} .020[.011]$ & $.017[.015]$ & $.016[.011]$ & ${ }^{\dagger} .020[.011]$ \\
\hline Length (days) $\in(1,3]$ & $* * * .058[.017]$ & $* * * .052[.013]$ & $* * * .051[.013]$ & $* * * .058[.017]$ & $* * * .052[.013]$ & $* * * .051[.013]$ \\
\hline Length (days) $\in(3,5]$ & $* * * .082[.021]$ & $* * * .073[.015]$ & $* * * .070[.015]$ & $* * * .084[.021]$ & $* * * .073[.015]$ & $* * * .070[.015]$ \\
\hline Length (days) $\in(5,7]$ & $* * * .076[.018]$ & $* * * .057[.014]$ & $* * * .057[.014]$ & $* * * .075[.018]$ & $* * * .057[.014]$ & $* * * .056[.014]$ \\
\hline Length (days) $\in(7,10]$ & $* * * .128[.036]$ & $* * * .104[.027]$ & $* * * .097[.027]$ & $* * * .124[.036]$ & $* * * .102[.027]$ & $* * * .091[.027]$ \\
\hline Buy It Now dummy & $* * * .100[.015]$ & $* * * .067[.011]$ & $* * * .064[.011]$ & $* * * .102[.016]$ & $* * * .068[.011]$ & $* * * .064[.011]$ \\
\hline Shipping (\$) & $* * *+.007[.001]$ & & & $* * *+.007[.001]$ & & \\
\hline Large seller Dummies & $\mathrm{N}$ & $\mathrm{N}$ & Y & $\mathrm{N}$ & $\mathrm{N}$ & $\mathrm{Y}$ \\
\hline
\end{tabular}

$* * *=$ significant at $\mathrm{p} \leq 0.001 ; * *=$ significant at $\mathrm{p} \leq 0.01 ; *$ significant at $\mathrm{p} \leq 0.05{ }^{\dagger}=$ significant at $\mathrm{p} \leq 0.10$

Notes: For each model there are 2,437 observations and 723 groups. The CHARITY variable is coded as 1 if the seller allocated a positive portion of final sales to a charity and 0 otherwise. The $10 \%$-SHARE variable is coded as 1 if the seller allocated $10 \%$ of the final sale price to charity and 0 otherwise; the $100 \%$ SHARE variable was coded as 1 if the seller allocated $100 \%$ of the final price to a charity and 0 otherwise, and MID-SHARE was coded as 1 if the seller allocated between 15 and $95 \%$ (inclusive) to a charity and 0 otherwise. The models contain a fixed effect for each product. Robust standard errors, clustered on product match, are in brackets. 
Table 4

Robustness Analysis of the Charity Premium

Dependent variable: Log (Price+Shipping)

\begin{tabular}{|c|c|c|c|c|c|c|c|c|}
\hline $\begin{array}{l}\text { Specification: } \\
\text { Column: }\end{array}$ & $\begin{array}{c}\text { Baseline } \\
\text { (1) }\end{array}$ & $\begin{array}{l}\text { No Buy-It- } \\
\text { Now } \\
(2)\end{array}$ & $\begin{array}{c}7 \text { day duration } \\
\text { (3) }\end{array}$ & $\begin{array}{l}\text { Day and time } \\
\text { dummies } \\
\text { (4) }\end{array}$ & $\begin{array}{l}\text { Middle } 50 \% \\
\text { Seller Rating } \\
\text { (5) }\end{array}$ & $\begin{array}{c}\text { Control for } \\
\text { opening price } \\
\text { (6) }\end{array}$ & $\begin{array}{l}\text { Control for } \\
\text { unique bidders } \\
\text { (7) }\end{array}$ & $\begin{array}{c}2+\text { unique } \\
\text { bidders } \\
(8)\end{array}$ \\
\hline $10 \%-S H A R E$ & $* * * .047[.014]$ & $* * .048[.016]$ & ${ }^{\dagger} .049[.025]$ & $* * * .046[.014]$ & $.024[.025]$ & $* * .045[.016]$ & $* * .046[.015]$ & $* * .046[.017]$ \\
\hline 100\%-SHARE & $* * * .070[.012]$ & $* * * .076[.014]$ & $* * * .084[.021]$ & $* * * .070[.012]$ & $* .058$ [.025] & $* * * .083[.014]$ & $* * * .078[.014]$ & $* * * .083[.015]$ \\
\hline MID-SHARE & $.025[.024]$ & $.023[.027]$ & $.011[.053]$ & $.023[.024]$ & $.038[.034]$ & $.022[.027]$ & $.024[.027]$ & $-.004[-.028]$ \\
\hline Buy-it-now included? & $\mathrm{Y}$ & $\mathrm{N}$ & $\mathrm{N}$ & $\mathrm{Y}$ & $\mathrm{Y}$ & $\mathrm{N}$ & $\mathrm{N}$ & $\mathrm{N}$ \\
\hline$N$ groups & 723 & 703 & 599 & 723 & 588 & 667 & 701 & 653 \\
\hline$N$ observations & 2,437 & 1,920 & 1,090 & 2,437 & 1,212 & 1,836 & 1,900 & 1,620 \\
\hline
\end{tabular}

$* * *=$ significant at $\mathrm{p} \leq 0.001 ; * *=$ significant at $\mathrm{p} \leq 0.01 ; *=$ significant at $\mathrm{p} \leq 0.05 ;^{\dagger}=$ significant at $\mathrm{p} \leq 0.10$

Notes: The $10 \%$-SHARE variable is coded as 1 if the seller allocated $10 \%$ of the final sale price to charity and 0 otherwise; the $100 \%$-SHARE variable was coded as 1 if the seller allocated $100 \%$ of the final price to a charity and 0 otherwise, and MID-SHARE was coded as 1 if the seller allocated between 15 and $95 \%$ (inclusive) to a charity and 0 otherwise. The models contain a fixed effect for each product. In addition to the charity variables plus any controls described in the column heading, we include the same set of control variables as in Table 3. Robust standard errors, clustered on product match, are in brackets. 
Table 5

Charity Premium Estimates and Product Value

\begin{tabular}{|c|c|c|c|c|}
\hline Dependent Variable: & Log Price & $\begin{array}{c}\text { Log (Price + } \\
\text { Shipping) }\end{array}$ & Log Price & $\begin{array}{c}\text { Log (Price }+ \\
\text { Shipping) }\end{array}$ \\
\hline Column: & (1) & (2) & (3) & (4) \\
\hline \multicolumn{5}{|l|}{ Charity Variables } \\
\hline \multicolumn{5}{|l|}{$10 \%-S H A R E$} \\
\hline$\times 0-25^{\text {th }}$ percentile & $* .091[.042]$ & $.046[.034]$ & $* .092[.042]$ & $.046[.034]$ \\
\hline$\times 25-50^{\text {th }}$ percentile & $.038[.031]$ & $.031[.025]$ & $.030[.031]$ & $.020[.026]$ \\
\hline$\times 50^{\text {th }}-75^{\text {th }}$ percentile & $* * .085[.030]$ & $* * .077[.028]$ & $.049[.030]$ & $.037[.028]$ \\
\hline$\times 75^{\text {th }}-100^{\text {th }}$ percentile & $.029[.024]$ & ${ }^{\dagger} .033[.019]$ & $.028[.024]$ & $.030[.019]$ \\
\hline \multicolumn{5}{|l|}{$100 \%-S H A R E$} \\
\hline$\times 0-25^{\text {th }}$ percentile & $* * * .246[.040]$ & $* * * .134[.025]$ & $* * * .235[.042]$ & $* * * .148[.027]$ \\
\hline$\times 25-50^{\text {th }}$ percentile & $* * * .140[.027]$ & $* * * .070[.020]$ & $* * * .130[.032]$ & $* * * .085[.022]$ \\
\hline$\times 50^{\text {th }}-75^{\text {th }}$ percentile & $* * .080[.031]$ & $* .059[.027]$ & $* * .087[.033]$ & $* * .078[.028]$ \\
\hline$\times 75^{\text {th }}-100^{\text {th }}$ percentile & $.011[.018]$ & $.015[.016]$ & $.022[.032]$ & ${ }^{\dagger} .028[.015]$ \\
\hline \multicolumn{5}{|l|}{ MID-SHARE } \\
\hline$\times 0-50^{\text {th }}$ percentile & $* .119[.027]$ & $.053[.035]$ & $* .117[.046]$ & $.053[.035]$ \\
\hline$\times 50^{\text {th }}-100^{\text {th }}$ percentile & $.002[.033]$ & $-.004[.029]$ & $.003[.033]$ & $-.005[.029]$ \\
\hline \multicolumn{5}{|l|}{ Auction \& Seller Characteristics } \\
\hline Log(Seller Rating) & $.004[.004]$ & $* .006[.003]$ & $.003[.004]$ & $* .006[.003]$ \\
\hline Seller Ratings $(\%)=100$ & $.033[.024]$ & $.014[.019]$ & $.029[.024]$ & $.009[.019]$ \\
\hline Seller Ratings $(\%) \in[99.5,100)$ & $.035[.026]$ & $.008[.020]$ & $.034[.026]$ & $-.001[.020]$ \\
\hline Seller Ratings $(\%) \in[99.0,99.5)$ & $.035[.027]$ & $.001[.022]$ & $.025[.027]$ & $.000[.022]$ \\
\hline Seller Ratings $(\%) \in[98.0,99.0)$ & $.009[.031]$ & $-.001[.023]$ & $.003[.031]$ & $-.008[.023]$ \\
\hline Power Seller dummy & $.017[.015]$ & $.016[.011]$ & $.019[.015]$ & $.017[.011]$ \\
\hline Length (days) $\in(1,3]$ & $* * * .061[.017]$ & $* * * .053[.013]$ & $* * * .060[.016]$ & $* * * .051[.013]$ \\
\hline Length (days) $\in(3,5]$ & $* * * .087[.021]$ & $* * * .075[.015]$ & $* * * .084[.021]$ & $* * * .072[.015]$ \\
\hline Length (days) $\in(5,7]$ & $* * * .076[.018]$ & $* * * .057[.014]$ & $* * * .074[.018]$ & $* * * .055[.014]$ \\
\hline Length (days) $\in(7,10]$ & $* * * .139[.037]$ & $* * * .110[.027]$ & $* * * .129[.036]$ & $* * * .097[.027]$ \\
\hline Buy It Now dummy & $* * * .102[.016]$ & $* * * .068[.011]$ & $* * * .100[.016]$ & $* * * .064[.011]$ \\
\hline Shipping (\$) & $* * *-.007[.001]$ & & $* * *-.007[.001]$ & \\
\hline Large seller Dummies & $\mathrm{N}$ & $\mathrm{N}$ & $\mathrm{Y}$ & $\mathrm{Y}$ \\
\hline
\end{tabular}

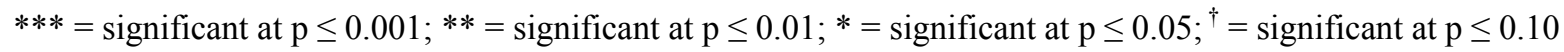

Notes: For each model there are 2,437 observations and 723 groups. Percentile cutoffs are based on the average price of all items in the matched set. The models contain a fixed effect for each product. Percentile cutoffs are $\$ 44$, \$93, and $\$ 146$ for $10 \%$-SHARE auctions, \$18, \$28, and \$60 for 100\%-SHARE auctions, and \$38 for MID-SHARE auctions. Robust standard errors, clustered on product match, are in brackets. 
Table 6

Bid Timing and Frequency

\begin{tabular}{|c|c|c|c|c|}
\hline Dependent Variable: & $\begin{array}{l}\text { Days before } \\
\text { Auction Close }\end{array}$ & $\begin{array}{l}\text { Days before } \\
\text { Auction Close }\end{array}$ & $\begin{array}{l}\text { Multiple Bids } \\
\text { for a Bidder? } \\
\quad(\text { Yes }=1)\end{array}$ & $\begin{array}{l}\text { Incremental } \\
\text { Bidder Wins? } \\
\quad(\text { Yes }=1)\end{array}$ \\
\hline Estimation Method: & $\begin{array}{l}\text { Fixed Effects } \\
\text { Regression }\end{array}$ & $\begin{array}{l}\text { Fixed Effects } \\
\text { Regression }\end{array}$ & Probit & Probit \\
\hline Column: & (1) & (2) & (3) & (3) \\
\hline \multicolumn{5}{|l|}{ Charity Variables } \\
\hline $10 \%-S H A R E$ & $.087[.100]$ & $.043[.175]$ & $.016[.021]$ & $-.039[.082]$ \\
\hline $100 \%-S H A R E$ & $* * * .428[.094]$ & $* * .505[.185]$ & ${ }^{\dagger} .037[.020]$ & $* .141[.062]$ \\
\hline MID-SHARE & $.279[.172]$ & $.192[.299]$ & $.009[.035]$ & $.007[.124]$ \\
\hline \multicolumn{5}{|l|}{ Auction \& Seller Characteristics } \\
\hline Log(Seller Rating) & ${ }^{\dagger} .043[.024]$ & $-.011[.056]$ & $.002[.006]$ & $-.011[.016]$ \\
\hline Seller Positive Ratings $(\%)=100$ & $.122[.123]$ & $.053[.293]$ & $.008[.026]$ & $.017[.088]$ \\
\hline Seller Positive Ratings $(\%) \in[99.5,100)$ & $-.107[.150]$ & $-.294[.378]$ & $.018[.035]$ & $.159[.103]$ \\
\hline Seller Positive Ratings $(\%) \in[99.0,99.5)$ & $.072[.155]$ & $-.318[.324]$ & $.006[.035]$ & $.048[.115]$ \\
\hline Seller Positive Ratings $(\%) \in[98.0,99.0)$ & $-.060[.170]$ & $.120[.367]$ & $.019[.036]$ & $.132[.115]$ \\
\hline Power Seller dummy & ${ }^{\dagger} .159[.092]$ & $.211[.236]$ & $-.013[.021]$ & $-.021[.066]$ \\
\hline Length (days) $\in(1,3]$ & $* .279[.114]$ & $*_{-} *_{-} .882[.252]$ & $.030[.029]$ & $.088[.082]$ \\
\hline Length (days) $\in(3,5]$ & $* * * .886[.136]$ & $.149[.286]$ & $.073[.030]$ & $.072[.095]$ \\
\hline Length (days) $\in(5,7]$ & $* * * 1.607[.133]$ & $* * .746[.258]$ & $.057[.026]$ & $.081[.078]$ \\
\hline Length (days) $\in(7,10]$ & $* * * 2.958[.307]$ & $* * * 2.095[.534]$ & $.089[.042]$ & $.129[.134]$ \\
\hline \multicolumn{5}{|l|}{ Bidder Characteristics } \\
\hline (Feedback rating / 1000) & $.086[.059]$ & & $* * *-.153[.027]$ & \\
\hline$(\text { Feedback rating / 1000 })^{2}$ & $*_{-.006}[.003]$ & & $* * * .005[.001]$ & \\
\hline Number of observations & 8,611 & 743 & 8,483 & 1,197 \\
\hline Number of groups & 546 & 333 & 515 & 349 \\
\hline
\end{tabular}

$* * *=$ significant at $\mathrm{p} \leq 0.001 ; * *=$ significant at $\mathrm{p} \leq 0.01 ; *=$ significant at $\mathrm{p} \leq 0.05 ;^{\dagger}=$ significant at $\mathrm{p} \leq 0.10$

Notes: The $10 \%$-SHARE variable is coded as 1 if the seller allocated $10 \%$ of the final sale price to charity and 0 otherwise; the $100 \%-S H A R E$ variable was coded as 1 if the seller allocated $100 \%$ of the final price to a charity and 0 otherwise, and MID-SHARE was coded as 1 if the seller allocated between 15 and 95\% (inclusive) to a charity and 0 otherwise. Robust standard errors, clustered on product match, are in brackets. 
Table A1

Examples of Rejected Matches

\begin{tabular}{ll}
\hline \hline Giving Works auction & Rejected match \\
\hline $\begin{array}{l}\text { \$100 Office Depot Gift Card with no } \\
\text { expiration date }\end{array}$ & Card value given as \$100 in auction title but \$99.62 in details \\
$\begin{array}{l}\text { First season of "Home Improvement" on } 3 \\
\text { DVDs in factory-sealed packaging }\end{array}$ & DVD set described as new but not in sealed packaging \\
$\begin{array}{l}\text { Callaway Great Big Bertha Warbird Driver } \\
\text { Golf Club with } 10^{\circ} \text { face angle }\end{array}$ & Same club model but with $11^{\circ}$ face angle \\
$\begin{array}{l}\text { Canon EOS Rebel GII 35mm Film Camera } \\
\text { with 80- 200 Zoom Lens }\end{array}$ & Same camera body but with 28-90 lens \\
$\begin{array}{l}\text { Bun and Thigh Roller Exercise Machine with } \\
\text { no accessories }\end{array}$ & Also includes instructional video and exercise guide \\
\hline \hline
\end{tabular}

